https://helda.helsinki.fi

\title{
White adipose tissue mitochondrial metabolism in health and in obesity
}

\section{Heinonen, Sini}

2020-02

Heinonen , S , Jokinen , R , Rissanen , A \& Pietiläinen , K H 2020 , ' White adipose tissue mitochondrial metabolism in health and in obesity ' , Obesity Reviews , vol. 21 , no. 2 , e12958 . https://doi.org/10.1111/obr.12958

http://hdl.handle.net/10138/313777

https://doi.org/10.1111/obr.12958

acceptedVersion

Downloaded from Helda, University of Helsinki institutional repository.

This is an electronic reprint of the original article.

This reprint may differ from the original in pagination and typographic detail.

Please cite the original version. 


\title{
White adipose tissue mitochondrial metabolism in health and in obesity
}

\author{
Sini Heinonen ${ }^{1}$ (D) | Riikka Jokinen ${ }^{1}$ | Aila Rissanen ${ }^{1,2}$ | Kirsi H. Pietiläinen ${ }^{1,3}$
}

\author{
${ }^{1}$ Obesity Research Unit, Research Program for \\ Clinical and Molecular Metabolism, Faculty of \\ Medicine, University of Helsinki, Helsinki, \\ Finland \\ ${ }^{2}$ Department of Psychiatry, Helsinki University \\ Hospital, Helsinki, Finland \\ ${ }^{3}$ Endocrinology, Abdominal Center, Helsinki \\ University Hospital, Helsinki, Finland
}

\section{Correspondence}

Kirsi H. Pietiläinen, MD, PhD, Obesity Research Unit, Biomedicum Helsinki, Helsinki University Central Hospital, C424b, PO Box 700, Haartmaninkatu 8, Helsinki 00029,

Finland.

Email: kirsi.pietilainen@helsinki.fi

\section{Funding information}

Academy of Finland, Grant/Award Numbers: 272376, 266286 and 314383; Emil Aaltonen Foundation; Finnish Diabetes Research Foundation; Finnish Government Research Funds; Helsinki University Central Hospital; University of Helsinki; Helsinki University Hospital Research Funds; Jalmari and Rauha Ahokas Foundation; Novo Nordisk Foundation; Gyllenberg Foundation; Finnish Cultural Foundation; Finnish Medical Foundation; Finnish Foundation for Cardiovascular Research

\begin{abstract}
Summary
White adipose tissue is one of the largest organs of the body. It plays a key role in whole-body energy status and metabolism; it not only stores excess energy but also secretes various hormones and metabolites to regulate body energy balance. Healthy adipose tissue capable of expanding is needed for metabolic well-being and to prevent accumulation of triglycerides to other organs. Mitochondria govern several important functions in the adipose tissue. We review the derangements of mitochondrial function in white adipose tissue in the obese state. Downregulation of mitochondrial function or biogenesis in the white adipose tissue is a central driver for obesity-associated metabolic diseases. Mitochondrial functions compromised in obesity include oxidative functions and renewal and enlargement of the adipose tissue through recruitment and differentiation of adipocyte progenitor cells. These changes adversely affect whole-body metabolic health. Dysfunction of the white adipose tissue mitochondria in obesity has long-term consequences for the metabolism of adipose tissue and the whole body. Understanding the pathways behind mitochondrial dysfunction may help reveal targets for pharmacological or nutritional interventions that enhance mitochondrial biogenesis or function in adipose tissue.
\end{abstract}

\section{KEYWORDS}

adipose tissue, mitochondria, obesity

\section{1 | INTRODUCTION}

Obesity is a global and rapidly increasing problem, tripled since 1975 by WHO 2018 standards in developed countries. Obesity is also extremely difficult to treat. A key defining feature of obesity is an adipose tissue dysfunction, which is considered to be a major contributor to the development of obesity-related metabolic problems, ${ }^{1,2}$ such as metabolic syndrome, insulin resistance, hypertension, dyslipidaemia, and fatty liver. The underlying pathological mechanisms that impair adipose tissue function in obesity are incompletely understood, but in the light of recent scientific advances, it may be connected to insufficient storage capacity or impaired function of mitochondria, or both.
Mitochondria are the energy centres of adipocytes and are involved in many of their key metabolic functions including ATP production, fatty acid synthesis and oxidation, and the triglyceride balance of the cell. Although adipose tissue was long considered as an inert reservoir of fat with low abundance of mitochondria, adipose tissue and its active mitochondria have recently emerged as one of the central regulators influencing whole-body metabolism. ${ }^{1,3,4}$ Impairments in adipocyte mitochondrial function are associated with metabolic diseases and the development of obesity-related disorders. ${ }^{3-6}$ Better understanding on the dysfunction of adipose tissue mitochondria may yield insights on how the metabolic complications of obesity could be reversed. In this review, we concentrate on the metabolic processes in white adipose tissue that are regulated by mitochondria 
and aim to highlight the functions of this organelle in current research on obesity and adipose tissue.

\section{2 | ADIPOSE TISSUE}

White adipose tissue is one of the largest organs of the body. Approximately $10 \%$ to $20 \%$ of total body weight in lean adults is white adipose tissue, but in individuals with obesity, the amount can increase ${ }^{7}$ up to $40 \%$ to $70 \%$. By harvesting excess lipids and glucose from the circulation, it protects other tissues from the pathological accumulation of triglycerides. ${ }^{2,8}$ When this storage capacity is disrupted, lipids may spill over into ectopic sites like internal organs and vasculature resulting in low-grade inflammation, insulin resistance, and metabolic problems. ${ }^{2,8,9}$ Intriguingly, both a total lack of adipose tissue in lipodystrophies and an unhealthy excess of adipose tissue in obesity lead to the same complications, including liver fat accumulation and insulin resistance. ${ }^{2,8}$ Moreover, adipose tissue is an active endocrine organ that regulates many metabolic responses at the whole-body level through adipocytokines. ${ }^{10}$ Changes in the main adipokines have been implicated in many obesity-related metabolic problems, such as type 2 diabetes, metabolic syndrome, and cardiovascular diseases.

Adipose tissue consists of adipocytes and a matrix, which includes collagen, blood and lymphatic vessels, and the stromal vascular fraction of adipose tissue with endothelial cells, smooth muscle cells, immune cells, adipocyte precursor cells (preadipocytes), and mesenchymal stem cells. ${ }^{11,12}$ Approximately $75 \%$ of adipose tissue weight and $95 \%$ of an adipocyte consist of triglycerides. The main depots of white adipose tissue are subcutaneous ( $80 \%$ to $90 \%$ of body fat), visceral ( $10 \%$ of body fat), and ectopic (intrahepatic, intramuscular, and intrapancreatic) fat. ${ }^{13,14}$ Different adipose depots have differences in capacity for adipocytokine secretion and cell type composition. ${ }^{15,16}$

In addition to white adipose tissue, also brown adipose tissue (BAT) and beige/brite adipose tissue (having mixed characteristics of both white and brown adipose cells) in humans exist. ${ }^{17-19}$ BAT has a distinctive brown colour, which originates from the high iron and cytochrome content of the dense network of mitochondria and vasculature within the tissue. $^{20}$ In contrast to the large unilocular triglyceride droplets in white adipocytes, brown adipocytes are composed of small, multilocular lipid droplets. BAT is the site of nonshivering thermogenesis, where the brown adipocyte-specific protein, uncoupling protein-1 (UCP1), physiologically uncouples the respiratory chain to generate heat, and its mitochondria could thus "burn" away fat. ${ }^{17}$ An extensive previous research shows that BAT function is impaired and its activity reduced in obesity. ${ }^{21,22}$ Cold-induced BAT glucose uptake and stimulation of blood flow are reduced in individuals with obesity ${ }^{23}$ as well as glucose uptake rates into BAT lower in both individuals with obesity and with type 2 diabetes. ${ }^{24}$ Studies have also shown that animals with more BAT are more resistant to obesity and type 2 diabetes. ${ }^{25,26}$ However, as the amount of BAT in human adults is very low, the clinical significance and contribution of BAT to energy expenditure are still debated. ${ }^{27}$ There is active research, reviewed elsewhere, on the possibilities of inducing "browning" of white adipose tissue or BAT function to treat obesity and its metabolic outcomes. ${ }^{27-29}$

This review concentrates on the mitochondria of white adipose tissue.

\section{3 | MITOCHONDRIA}

Mitochondria are essential for key adipose tissue functions (Figure 1). Mitochondria produce energy in the form of ATP through oxidative phosphorylation (OXPHOS), generate substrates for cell metabolism (eg, de novo fatty acid synthesis), regulate lipid turnover, and control the generation of new adipocytes and adipokine secretion. ${ }^{3,30}$

Mitochondria are double-membrane organelles with an outer and an inner membrane and an intermembrane space. The inner membrane is folded into cristae and surrounds a mitochondrial matrix, where many chemical reactions of energy metabolism take place. Mitochondria possess their own genome, a circular mitochondrial DNA (mtDNA), which encodes 13 proteins critical for OXPHOS and two ribosomal and 22 transfer RNAs required for mitochondrial ribosomes and translation, respectively. ${ }^{31,32}$ In addition, over one thousand mitochondrial proteins, including essential proteins of OXPHOS, mitochondrial translation, and other mitochondrial processes are encoded by nuclear DNA. ${ }^{31,33,34}$

\subsection{Mitochondrial oxidative energy metabolism}

The main energy derivation pathways of the cell, including pyruvate oxidation, fatty acid $\beta$-oxidation, the tricarboxylic acid (TCA) cycle, and OXPHOS, occur in mitochondria (Figure 1). ${ }^{35}$

In aerobic energy production through OXPHOS, high-energy electrons (derived from substrate oxidation) are transferred through the electron transport chain in the inner mitochondrial membrane (complexes I-IV of the OXPHOS system). The electron transport is coupled with proton pumping at complexes I, III, and IV, generating an electrochemical potential difference across the inner membrane. The energy of the gradient is utilized by complex $V$ (ATP synthase) to phosphorylate ADP to ATP. ${ }^{36}$

The TCA cycle is the final common oxidative pathway for all substrates (carbohydrates, fatty acids, and amino acids) and generates the high-energy electron carriers $\left(\mathrm{NADH}\right.$ and $\left.\mathrm{FADH}_{2}\right)$ that supply OXPHOS, energy compounds ATP and GTP, and metabolites needed as carbon skeletons for many biosynthetic processes of the cell, such as de novo fatty acid synthesis.

Pyruvate derived from glucose is transported to the mitochondria and oxidized in the matrix yielding acetyl-CoA. The pyruvate dehydrogenase complex catalyses the reaction and controls the amount of acetyl-CoA fed into the TCA cycle.

Free fatty acids (FFAs) are metabolized, esterified, or $\beta$-oxidized in adipocyte mitochondria. The long-chain fatty acids are transported from the cell cytosol into the mitochondrial matrix by carnitine palmitoyltransferases (CPTs; CPT1, CACT, and CPT2). ${ }^{37} \beta$-oxidation of the fatty acids produces acetyl-CoA, which enters the TCA cycle. 
Catabolism of branched-chain amino acids (BCAA, ie, leucine, isoleucine, and valine) also occurs in mitochondria. Branched-chain amino acid aminotransferase (BCAT) forms a-ketoacids (BCKAs) from BCAAs via both cytosolic (BCATc, BCAT1) and mitochondrial (BCATm, BCAT2) isoenzymes. ${ }^{38}$ The BCKAs are transported into mitochondria, where they are decarboxylated by the mitochondrial branched-chain a-ketoacid dehydrogenase (BCKD) complex. Finally, the products are used in the TCA cycle.

\section{2 | Energy-status-dependent regulation of mitochondria}

By changing the morphology, distribution, and mass of mitochondria, the cell adapts to different energetic and metabolic demands. ${ }^{39}$ Mitochondria are remodelled by fusion and fission, and changes in their rate of biogenesis and distribution in the cell are frequent. ${ }^{40,41}$ Studies on mitochondrial remodelling in adipose tissue are, however, sparse. Mitochondrial network fragmentation and fission appears to improve mitochondrial bioenergetics and make adipose tissue more insulin sensitive. ${ }^{42}$ This is in contrast to skeletal muscle, where fission contributes to insulin resistance. ${ }^{43}$

The energy status of the cell is signalled through the $\mathrm{NAD}^{+}$: $\mathrm{NADH}$ ratio, the AMP:ATP ratio, and acetyl-CoA levels, ${ }^{44,45}$ which sense the signals of mitochondrial activity. AMP-activated protein kinase (AMPK) is activated when AMP levels are high. This induces oxidative phosphorylation and suppresses cell growth and proliferation. ${ }^{45} \mathrm{NAD}^{+}$-dependent deacetylase sirtuin 1 (SIRT1) is activated when $\mathrm{NAD}^{+}$levels are high, and this upregulates mitochondrial mass, ATP generation, and nutrient oxidation. Both AMPK and SIRT1 activate the peroxisome proliferator-activated receptor gamma coactivator 1 alpha (PGC-1a). PGC-1a is one of the main inducers of mitochondrial oxidative metabolism, has a major role in mitochondrial biogenesis, ${ }^{46}$ and interacts with many mitochondria-related transcription factors. ${ }^{47}$ In energy excess, PGC-1a is acetylated and silenced. Caloric restriction leads to PGC-1a activation through SIRT1. ${ }^{48}$ An activated PGC-1a induces oestrogen-related receptor a (ERRa) and GA-binding protein a (GABPa), which increase the function of the OXPHOS complexes including cytochrome $c$ and ATP synthase. ${ }^{49,50}$ PGC-1a enhances nuclear respiratory factor 1 (NRF-1), which is needed for the induction of mitochondrial biogenesis ${ }^{51}$ and TFAM, which controls mtDNA stability and the transcription of mtDNAencoded genes. $^{52}$ Transcription factor Forkhead box O 1, FOXO1, enhances adipogenesis ${ }^{53}$ and controls adipocyte stress response. ${ }^{54}$ Also, mitochondrial DNA methylation may be a control factor of mitochondria, although recent studies have challenged its existence altogether. ${ }^{55,56}$

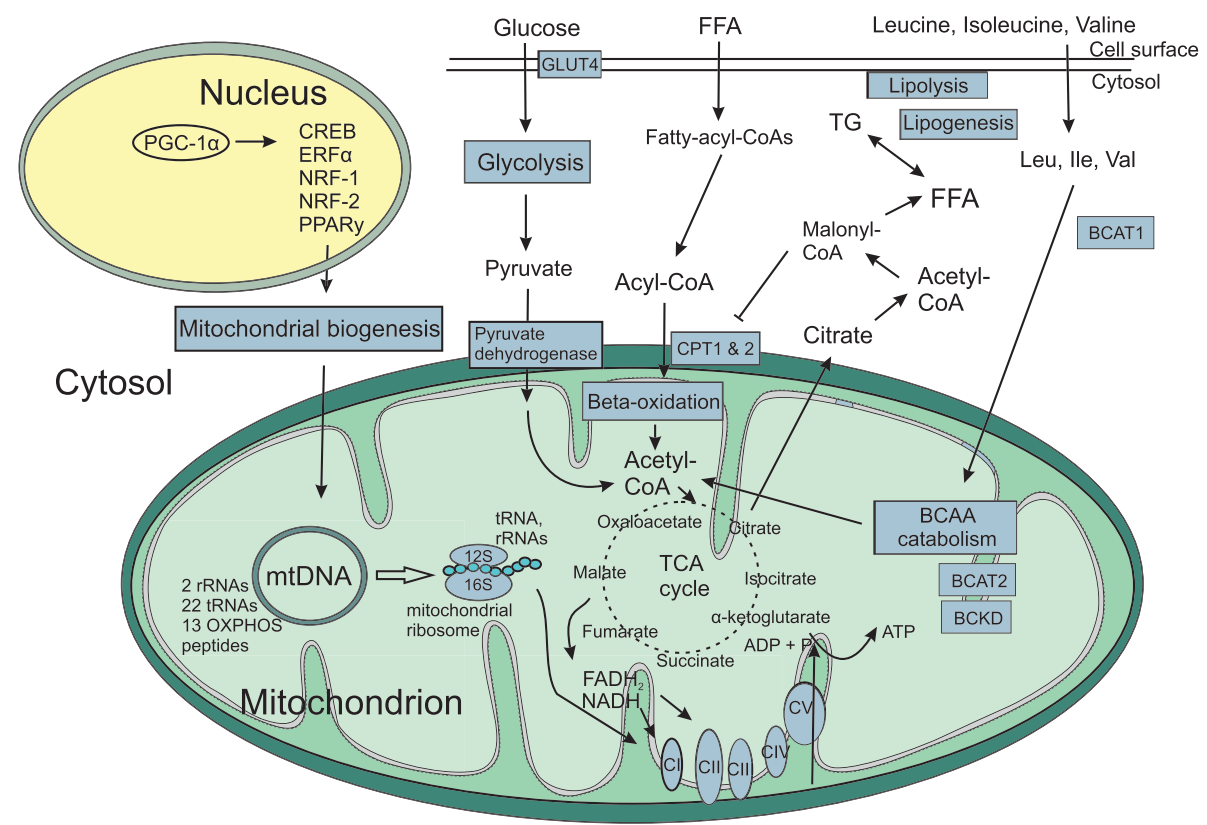

FIGURE 1 Normal mitochondrial function in adipose tissue. Mitochondria (in green) are regulated by various nuclear-related transcription factors. Most of the regulators are under the influence of PGC-1a (in nucleus, yellow background). In normal conditions, transcription factors enhance mitochondrial biogenesis and function. MtDNA (green circle) encodes proteins critical for mitochondrial ribosomes (12S and 16S subunits, in grey) and for the OXPHOS complexes (in the mitochondrial membrane, in grey). The translation of these proteins is processed in the mitochondrial ribosomes. Glucose, FFA, and BCAAs derived from nutrients (above the two lines, cell surface) are used for the energy production and other maintenance functions of the cell. Glucose is converted into pyruvate via glycolysis, and pyruvate-derived acetyl-CoA enters the TCA-

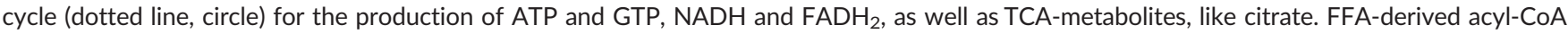
enters beta-oxidation and acetyl-CoA further to TCA cycle. BCAAs are catabolized via BCAT1 in cytosol and BCAT2 in mitochondria. BCKD complex frees acetyl-CoA into the TCA cycle. Citrate is used for biosynthetic processes of the cell, like production of other TCA metabolites and as precursor for lipogenesis as malonyl-CoA, which also inhibits beta-oxidation through CPT1 transporters. Mark explanations: an arrow, induction; a T-line, inhibition; green area, mitochondrion; yellow area, cell nucleus 


\section{4 | MITOCHONDRIAL METABOLISM IN WHITE AT IN HEALTH AND IN OBESITY}

\section{1 | Mitochondrial oxidative metabolism in white AT is altered in obesity}

In recent decades, altered mitochondrial oxidative metabolism has emerged as a molecular hallmark of obese adipose tissue (Figure 2).

Reduction of mitochondrial oxidative metabolism in adipose tissue in obesity ${ }^{57,58}$ and in diabetes ${ }^{59}$ has been demonstrated in several animal studies: In diet-induced or genetic mouse models of obesity, limited OXPHOS capacity, measured by maximal respiration capacity and cell respiratory control ratios via cell respirometer, was observed in white adipocytes, both in the absence and the presence of impaired glucose tolerance. ${ }^{58}$ The authors concluded that impairments in mitochondria relate to obesity, not to glucose intolerance. ${ }^{58}$ Mitochondriarelated transcription was reduced, and mitochondrial staining, DNA quantification, and measurements of citrate synthase activity revealed reduced mitochondrial biogenesis in both obesity and diabetes. ${ }^{60}$ The gene transcripts encoding mitochondrial proteins were decreased in obese mice without diabetes. ${ }^{57}$ After treatment with rosiglitazone, half of the genes were upregulated, and the change was accompanied by an increase in mitochondrial mass. ${ }^{57}$ However, another study found reduced levels of OXPHOS mitochondrial protein subunits, cellular mitochondrial DNA content by qPCR, oxygen consumption by cell respirometer, and number of mitochondria by MitoTracker staining and electron microscopy in diabetic, but not obese mice. ${ }^{59}$

Also, several human studies have linked obesity to mitochondrial dysfunction and to impaired glucose and lipid metabolism in adipose tissue. ${ }^{3,4,30}$ We have previously shown that mtDNA amount and gene expression levels of mitochondria-related pathways are downregulated in co-twins with obesity compared with their co-twins who are lean, a rare study setting that distinguishes the acquired features of obesity from potential genetic effects. ${ }^{61}$ Moreover, we have demonstrated downregulation of mitochondrial biogenesis in these twins with obesity compared with their lean identical co-twins by reduced expression of genes encoding for mitochondrial proteins, expression of PGC-1a, mtDNA amount, expression levels of mtDNA-encoded transcripts and mitochondrial ribosomal protein subunits, and, finally, reduced levels of OXPHOS complex subunits. ${ }^{62}$ The reduced expression of nuclear-encoded mitochondria-related genes, PGC-1a, and reduction of mtDNA-encoded transcripts were recapitulated in isolated primary mature adipocytes of the identical twins and the reduced levels of OXPHOS protein subunit levels in the adipocytes of unrelated individuals with obesity versus lean individuals. ${ }^{63}$ In within-pair extensive genome-wide DNA methylation analysis, we have previously identified 17 differentially methylated obesityassociated genes. ${ }^{64}$ These genes clustered to downregulated lipid metabolism by mitochondria, downregulated adipogenic genes with upregulated inflammation, and extracellular matrix (ECM) remodelling. Additionally, we have shown hypermethylation in the co-twins with obesity in two CpG sites within the gene body of PGC-1a, with methylation in one of the CpG sites correlating with PGC-1a expression. ${ }^{62}$ imilar results have been obtained in studies of unrelated individuals. Downregulation of mitochondrial mtDNA in individuals with obesity has been shown by several studies, ${ }^{61,62,65-69}$ although not all. ${ }^{70-72}$ The expression of PGC- $1 a^{73}$ and the activities of the OXPHOS complexes I to IV, mitochondrial phosphate utilization, and mitochondrial membrane potential ${ }^{74}$ were downregulated in subcutaneous adipose tissue of patients with obesity, compared with lean controls. The activities of the OXPHOS complexes were reduced in simple obesity and in obesity with diabetes. ${ }^{74}$ Obesity also links to decreased levels of OXPHOS complexes I and IV ${ }^{75}$ in adipocytes, decreased mitochondrial oxygen consumption rates in isolated adipocyte mitochondria, ${ }^{71,75}$ and reduced oxygen consumption rates in preadipocytes after beta-adrenergic stimulation. ${ }^{71}$ A study with human preadipocytes has revealed changes in the methylation pattern of the preadipocytes obtained from individuals with obesity, with loss of DNA methylation in selected regions, where adipogenesis, inflammation, and immunosuppression were the most affected pathways. ${ }^{76}$

Proteomic studies revealed that BMI was inversely associated with four important omental adipose tissue mitochondrial proteins-citrate synthase, HADHA, LETM1, and mitofilin. ${ }^{77}$ A lower abundance of mitochondrial proteins in subcutaneous adipose tissue has been recorded in insulin resistance without the presence of obesity ${ }^{78}$ and in visceral fat of individuals with type 2 diabetes. ${ }^{79}$ These studies suggest changes in the mitochondrial proteome with metabolic disorders in general, but exact studies on obesity have yet to be performed.

Primary mitochondrial defects in adipose tissue affect metabolic health also in transgenic mice. The results here, however, seem more pronounced and somewhat contradictory than in acquired obesity. ATP depletion by knocking out the TCA enzyme fumarase hydrogenase in white and brown adipocytes resulted in low adipose mass, small adipocytes, and protection against obesity, insulin resistance, and fatty liver despite a high-fat diet. ${ }^{80}$ Mice genetically overexpressing prohibitin (needed in adipocyte differentiation) had enhanced mitochondrial biogenesis and consequently developed obesity. ${ }^{69}$ These studies suggest that mitochondrial downregulation in adipose tissue could be beneficial, raising the question if the downregulation of mitochondria in obesity is a compensatory mechanism. However, this may not be the case as in another study with an adipose-specific TFAM-knockout mice model to simulate mitochondrial dysfunction, the mice became lipodystrophic and developed mitochondrial dysfunction, fatty liver, insulin resistance, and hypertension. ${ }^{81}$ Nevertheless, the conditions in these primary genetic-model studies are not directly comparable with obesity in humans and mice, where mitochondrial downregulation relates to obesity and metabolic problems. The mice in the studies had primary mitochondrial defects, while the decrease of mitochondrial function occurring in obesity is milder, possibly involving many different aspects of mitochondrial function.

\subsection{Fatty acid oxidation is impaired in obesity}

Adipocytes both generate and oxidize lipids. During nutrient excess, glucose metabolism and lipogenesis produce malonyl-CoA, which 
inhibits the import of fatty acids to mitochondria through the CPT1 transporter, decreasing fatty acid oxidation. In low energy status, AMPK activation decreases malonyl-CoA, ${ }^{82}$ resulting in enhanced CPT1 activity and $\beta$-oxidation. Sirtuins regulate AMPK and have lately emerged as important modulators of lipid metabolism and fatty acid oxidation. ${ }^{83}$

In obesity, mitochondrial fatty acid oxidation is suggested to be impaired, ${ }^{4}$ at least in subcutaneous adipose tissue. ${ }^{84}$ Obese rats have impaired fat oxidation and reduced CPT1 mRNA levels in intraabdominal adipose tissue. ${ }^{85} \mathrm{CPT} 1 \mathrm{~A}$ overexpression in cultured adipocytes in turn has enhanced fatty acid oxidation, improved insulin sensitivity, and decreased inflammation. ${ }^{86}$ However, as only modest activity of CPT1 in adipose tissue has been suggested, it has been questioned whether the changes in the levels of CPT1 have significance in obesity. ${ }^{87}$ On the other hand, in mice study, an adipose-specific knockout of CPT2A of mitochondrial long-chain fatty acid $\beta$-oxidation compromised fatty acid oxidation in adipose tissue but reduced highfat diet-induced oxidative stress, ROS production, and inflammation compared with normal mice. ${ }^{88}$ These results may indicate that an intricate balance of fatty acid oxidation may be needed-enough to prevent excess accumulation of triglycerides in adipose tissue and FFA flux to other tissues, but not in excess leading to inflammation in the tissue.

\section{3 | BCAA oxidation is downregulated in obesity}

Adipose tissue is one of the main sites of mitochondrial BCAA catabolism. ${ }^{89}$ BCAAs function as nutrient signals of amino acids, total food intake, and energy balance. ${ }^{90,91}$ They regulate insulin secretion, protein synthesis, and protein breakdown in adipose, liver, and muscle tissues. ${ }^{90,91}$ Already in the 1970 s, adipose tissue was suggested to be important in the conversion of excess BCAA into fat ${ }^{92}$; the ability of which was confirmed only in $2010 .^{89}$

In insulin resistance and in obesity, downregulation of BCAA oxidation enzymes and transcription of genes involved in BCAA oxidation in adipose tissue has been reported several times (Figure 2), ${ }^{61,62,91,93-95}$ as have elevated levels of BCAAs in the blood stream. ${ }^{61,96}$ The BCAA levels in circulation rise with decreased oxidation. ${ }^{89}$ Increased plasma BCAA levels are associated with type 2 diabetes, ${ }^{97}$ insulin resistance, ${ }^{98}$ metabolic syndrome and cardiovascular diseases. ${ }^{99,100}$ In contrast, BCAA-rich diets in mice on high-fat diet resulted in improved glucose metabolism and lower body weight compared with controls on high-fat diet without BCAA supplement. ${ }^{101}$ The study, however, did not measure serum BCAA levels. Interestingly, elevated plasma levels of BCAA but improved insulin sensitivity and increased energy expenditure were observed in all-tissue BCATm-knockout mice. ${ }^{102}$ Increased levels of BCAAs in circulation have been suggested to be contributors to the development of insulin resistance through the accumulation of mitochondriotoxic metabolites, which promote pancreatic $\beta$-cell dysfunction, apoptosis, and stress signaling. ${ }^{90}$ Insulin resistance has indeed been shown to result in increased protein degradation in tissues, ${ }^{90}$ leading to increased levels of amino acids and BCAAs in the circulation. Furthermore, persistent activation of the mammalian target of rapamycin complex 1 (mTORC1) by BCAAs appears to lead to uncoupling of the insulin receptor from the insulin signalling mediator (IRS-1) and to further insulin resistance. ${ }^{90}$ It is unknown if the same mechanisms are involved in adipose tissue.

\subsection{Glucose oxidation is reduced in obesity}

In high-fat-fed mice, metabolites related to glucose oxidation in the mitochondrial matrix are decreased, with a nearly $50 \%$ reduction in the levels of 1,5-anhydroglycitol (1,5-AG), which is a marker of shortterm glycaemic control in plasma. ${ }^{103}$ The levels of glucose-6-phosphate of glycolysis were decreased, and the expression of Pdk4, an inhibitor of mitochondrial pyruvate dehydrogenase activity, was diminished, suggesting aberrant glucose oxidation with high-fat diet. ${ }^{103}$

Mitochondrial glucose oxidation in adipose tissue is studied less in humans, and there is not yet direct evidence on decreased oxidation or increased glycolytic activity in human obesity. Comparisons between male and female subjects have shown that preadipocytes, but not mature adipocytes from female subjects, show higher mitochondrial to glycolytic activity in normoglycaemic conditions. ${ }^{104}$ When challenged with extra glucose and insulin, preadipocytes from female donors reduce their ATP-linked mitochondrial respiration, possibly as a marker of greater insulin sensitivity, with both male and female preadipocytes increasing their glycolytic activity. ${ }^{104}$ This might indicate changes in oxidative versus glycolytic activity with excess energy; however, more studies are needed to draw conclusions on the subject.

\section{5 | Mitochondrial respiration and adipose tissue oxygen levels}

Mitochondrial energy metabolism in the cell is oxygen dependent. Adipose tissue was previously suggested to be oxygen deprived in obesity, as the adipocytes enlarge beyond the oxygen diffusion limit ${ }^{105}$ of approximately $100 \mu \mathrm{m}$. Hypoxia was considered as one of the inducers of inflammation, because preadipocytes obtained from individuals with obesity cultured in hypoxic conditions secreted more inflammatory markers. ${ }^{106}$ In rodent models of obesity, rapid weight gain is accompanied with increased expression of genes related to hypoxia, lower partial oxygen pressure, and an increase in hypoxic areas in adipose tissue. ${ }^{107,108}$ Also, decreasing adipocyte oxygen consumption and hypoxia by Ant2 knockdown in obese mice has led to decreased inflammation and improved glucose tolerance. ${ }^{109}$ In human obesity, oxygen pressure in adipose tissue has been reported as reduced in individuals with obesity versus lean individuals. ${ }^{110} \mathrm{How}$ ever, recent new studies have questioned the view of hypoxia in adipose tissue in obesity. A study by Goossens et al has found increased oxygen pressure in adipose tissue of individuals with obesity. ${ }^{111}$ The latter study was matched for age, gender, presence of type II diabetes, and ethnicity, and the results were later replicated in a weight-loss study by the same group, where 5 -week very low-calorie diet in individuals with obesity decreased adipose tissue oxygen pressure. ${ }^{112}$ Also, no significant differences have been found between persons with obesity and lean persons in relation to secretion of the adipose 
tissue hypoxic markers lactate and pyruvate. ${ }^{113}$ Based on these results, it has been suggested that the oxygen consumption of adipose tissue is reduced in obesity, resulting in higher adipose tissue partial oxygen pressure despite the lower blood supply. ${ }^{114}$ As mitochondrial oxidative metabolism is an important consumer of cellular oxygen, these studies can be considered as indirect evidence for low mitochondrial oxidative metabolism in adipose tissue in obesity.

\subsection{Lipogenesis and lipolysis may be impaired in obesity}

Active mitochondria are needed in both lipogenesis and lipolysis. Mitochondria are essential in generating the intermediary metabolites needed for de novo fatty acid synthesis ${ }^{3}$ such as TCA-cycle-derived acetyl-CoA for fatty acid synthesis and esterification into triglycerides with glycerol-3-phosphate. ${ }^{115}$ In mouse studies, the rate of lipogenesis decreases with interventions that reduce mitochondrial ATP generation. ${ }^{116,117}$ Conversely, the amount of mtDNA shows a strong positive correlation with the rate of lipogenesis in human adipocytes. $^{65}$ Thus, mitochondrial dysfunction may be connected to impaired lipogenesis.

During fasting, adipose tissue releases FFA by lipolysis via the function of hormone-sensitive lipase $(\mathrm{HSL})^{118}$ and adipose triglyceride lipase (ATGL). ${ }^{119}$ Lipolysis and mitochondrial ATP syntheses were first shown to be coupled in 1975, when inhibitors of the electron transport chain shut down catecholamine-induced lipolysis. ${ }^{120}$

During exercise or fasting, persons with obesity appear to have a lower capacity for lipolysis than lean persons, while in the fed state, lipolysis is insufficiently suppressed due to the insulin resistance of the adipose tissue, leading to hypertriglyceridemia. ${ }^{121}$ Hypertriglyc eridemia has a major role in the aetiology of insulin resistance. ${ }^{5,122}$ Nevertheless, mice with an ATGL and HSL full-body knockout exhibit increased fat mass and lipid accumulation in insulin-sensitive tissues, however with inconsistent results on the insulin sensitivity of the animals. ${ }^{123}$ Moreover, the levels of adipose tissue ATGL and HSL are shown to be decreased in insulin-resistant individuals with obesity. ${ }^{124}$ In human multipotent adipose stem cell (hMADS) adipocytes, a knockdown or pharmacological inhibition of ATGL and HSL increased lipid accumulation and insulin resistance and leads to reduced mitochondrial oxygen consumption and impaired PPARa signaling. ${ }^{125}$ The authors of the human and hMADS studies suggest HSL and ATGL deficiency as a compensatory mechanism, which tries to decrease lipid flux into the circulation while simultaneously impairing adipocyte function. Interestingly, inefficient lipolysis has recently been linked to future weight gain and suggested to be a marker for identifying risk individuals for the prevention of obesity. ${ }^{126}$

\subsection{Adipokine secretion is altered in obesity}

Adipocytes and adipose tissue matrix cells secrete a variety of adipocytokines. These adipokines regulate energy intake and expenditure, body weight, glucose and lipid metabolism, insulin sensitivity and inflammation, ${ }^{127,128}$ generation of preadipocytes, ${ }^{129}$ and the migration of the cells in adipose tissue, ${ }^{130}$ acting as hormones, or in an autocrine or paracrine fashion within adipose tissue.

Leptin and adiponectin are the main adipokines that are exclusively secreted by adipocytes. Leptin decreases food intake and energy consumption by acting on the hypothalamus and target tissues, ${ }^{131}$ increases insulin sensitivity, ${ }^{120}$ stimulates lipolysis by increasing CAMP concentrations in the cell, ${ }^{132}$ and can activate inflammatory cytokine secretion. ${ }^{133}$ However, apart from increasing cAMP concentrations, direct data on the relationship between leptin and mitochondria in the literature are sparse and still remain to be studied.

Adiponectin stimulates fatty acid oxidation, improves glucose metabolism and insulin sensitivity, and decreases plasma FFA levels in adipose tissue ${ }^{134}$ by inhibiting lipolysis. ${ }^{135}$ Adiponectin is also an anti-inflammatory molecule. ${ }^{136} \mathrm{~A}$ decrease or an increase in mitochondrial biogenesis directly inhibits or enhances adiponectin secretion and synthesis in adipocytes. ${ }^{137}$ This is evidenced also by inhibition of the electron transport chain or deletion of mitochondrial transcription factor A, which both lead to reduced adiponectin secretion. ${ }^{138}$ Furthermore, hypertrophied adipocytes with diminished mitochondrial capacity have reduced synthesis of adiponectin. ${ }^{139}$ In adipose tissue, adiponectin has been shown to block the mitochondrial apoptosis pathway by activating AMPK signalling and inhibiting ER stressinduced apoptosis. ${ }^{140}$ These studies introduce adipocyte mitochondrial function as a potential target to restore adiponectin secretion and levels in obesity and related metabolic disorders.

\subsection{Mitochondria in adipogenesis}

The renewal and maintenance of adipose tissue are achieved by preadipocytes. These cells are derived from adipose tissue stem cells, ${ }^{141,142}$ which reside in adipose tissue vascular stroma. ${ }^{142,143}$ Adipogenesis consists of two main steps: commitment of a pluripotent progenitor population to a preadipocyte lineage and terminal differentiation, in which the preadipocytes differentiate into mature functional adipocytes. Impairments in adipogenesis have been suggested to lead to accumulation of ectopic fat and insulin resistance. ${ }^{2}$

Mitochondria are essential in adipocyte differentiation and adipogenesis. ${ }^{3}$ Mitochondrial biogenesis and adipogenesis are intertwined processes tightly coordinated by the same transcription factors. PPAR $\gamma,{ }^{144} \mathrm{C} / \mathrm{EBPa}^{144} \mathrm{CREB},{ }^{3,145}$ oestrogen-related receptor a $(E R R a),{ }^{146}$ and PGC-1a are all major regulators of both adipogenesis and mitochondrial biogenesis ${ }^{147,148}$ of which specifically PPAR $\gamma$ is a powerful inducer of adipogenesis. Mitochondrial biogenesis is thought to be under the control of adipogenic gene expression. ${ }^{3,148}$ Various mitochondrial modifications take place during adipogenesis, ${ }^{149}$ and mitochondria provide the essential substrates necessary for lipogenesis during adipogenesis. ${ }^{115} \mathrm{~A} 20$ - to 30 -fold increase in the amount of mitochondrial proteins has been recorded during adipocyte differentiation, ${ }^{149}$ and the oxygen consumption of the preadipocytes increases in parallel to increased mitochondrial biogenesis. ${ }^{149}$ The link between adipogenesis and mitochondrial biogenesis is reinforced also by the 


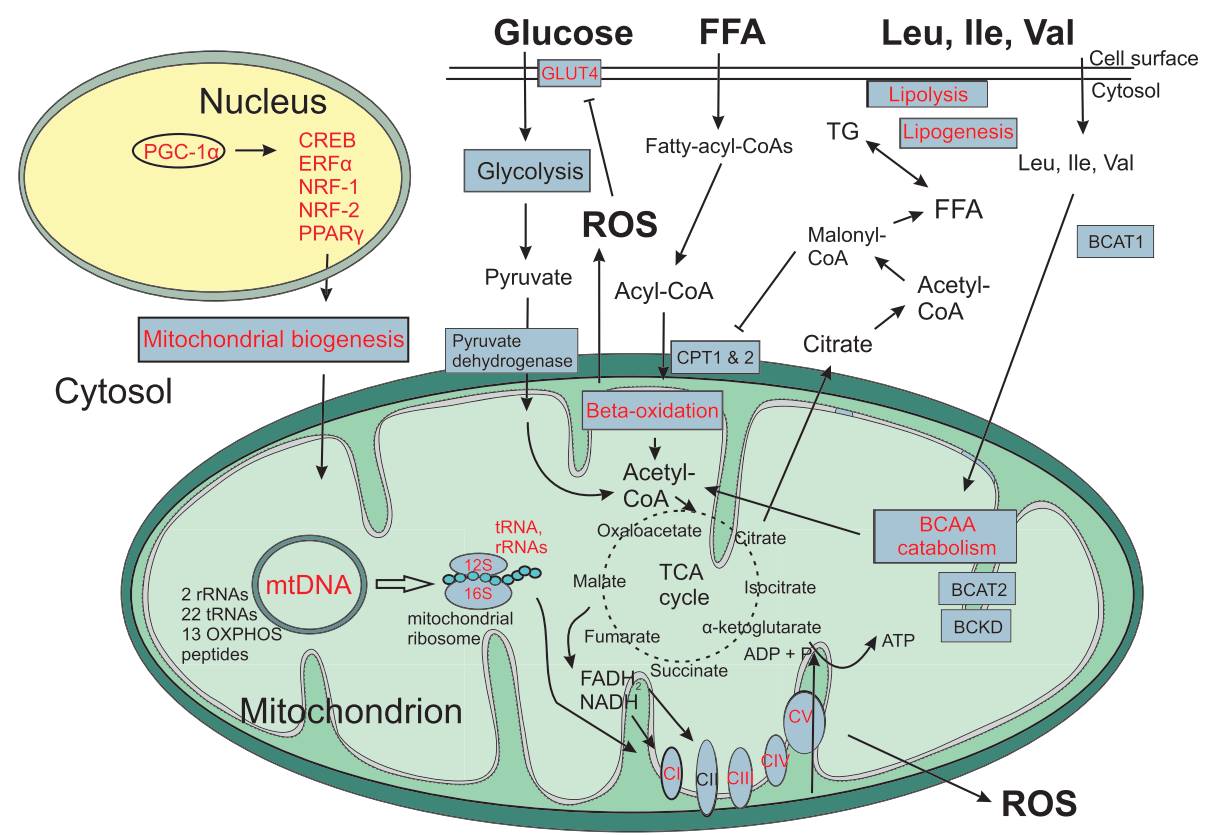

FIGURE 2 Mitochondrial dysfunction in adipose tissue in obesity. Steps leading to mitochondrial dysfunction: Downregulation of the nuclear transcription factors (red text) results into downregulation of mitochondrial biogenesis (in red) and adipogenesis with reduced mtDNA amount (red), reduced mitochondrial ribosomal transcripts (red), reduced OXPHOS transcripts and protein subunit levels (red). Reduction in the GLUT4 translocation (red) to adipocyte cell membrane reduces glucose uptake into adipose tissue and thus the levels of pyruvate available for TCA. Excess FFAs (in bold text) impair beta-oxidation (in red), with the production of excess ROS (bold) and possible intermediary oxidative metabolites. These further derange cell functions. Changes in lipogenesis and lipolysis (in red) take place, favouring fat storage; however, with also impairments in lipolysis. BCAA catabolism (in red) is downregulated yielding less Acetyl-CoA available for TCA. Mark explanations: text in red, downregulated in obesity; an arrow, induction; a T-line, inhibition; bolded text, increased in obesity

fact that the PPARy agonist rosiglitazone induces alterations in mitochondrial morphology and density. ${ }^{57}$

Interestingly, BCAA catabolism and utilization of BCAA-derived carbon skeletons (through the TCA cycle) for fatty acid synthesis also increase during the differentiation, ${ }^{150}$ potentially fuelling the process. ${ }^{151}$ Mitochondrial metabolism of BCAAs also stimulates increase in fat cell mass, adipose tissue lipid uptake, and differentiation by activating mTORC and thus PPAR $y$ signaling. ${ }^{90,152}$

In animal studies, pharmacologically inhibiting complex I or the ATP synthase inhibits the proliferation ${ }^{153}$ and differentiation of preadipocytes in mice. ${ }^{154}$ In mouse 3T3-L1 preadipocytes, mitochondrial dysfunction induced by a complex III inhibitor leads to abnormal triglyceride accumulation, reduced expression of adipogenic markers, and to impaired differentiation. ${ }^{145}$ In rat preadipocytes, inhibition of complex I resulted in inhibition of preadipocyte differentiation with reduced ATP synthesis and downregulated gene expression of fattyacid synthase, LPL, PPAR $\gamma, C / E B P a$, and SREBP-1c. ${ }^{155}$

Adipogenesis and the enlargement of adipose tissue are seen as a crucial mechanism that protects other tissues from triglyceride accumulation, insulin resistance, and metabolic dysfunction.

\subsection{Mitochondria in adipocyte hypertrophy and hyperplasia in obesity}

Adipose tissue enlarges by adipocyte hypertrophy (increase in cell size), hyperplasia (increase in cell number), or both (Figure 3).
Mitochondria regulated lipogenesis and adipogenesis and thus may affect the hypertrophy versus hyperplasia of the tissue. The number of adipocytes in adipose tissue is determined by the differentiating preadipocytes and the recruitment of mesenchymal stem cells for differentiation. ${ }^{156}$ In general, cellular hypertrophy is associated with insulin resistance, ${ }^{157-159}$ hepatic steatosis, dyslipidemia, ${ }^{160}$ elevated levels of circulating inflammatory markers, ${ }^{161}$ increased inflammatory gene expression, ${ }^{162}$ and increased number of macrophages in adipose tissue. ${ }^{163,164}$ Hyperplasia in turn seems to preserve insulin sensitivity ${ }^{158,165}$ and a favourable secretion of signalling molecules in adipose tissue. $^{163}$

Adipocyte renewal and turnover-10\% of the cells each yearoccurs throughout life, although the number of adipocytes in an individual appears to be stable and determined early in adulthood. ${ }^{166}$ Adipocyte number does not differ between co-twins with obesity compared with their lean $\mathrm{MZ}$ co-twins, suggesting a strong genetic control of this measurement. ${ }^{167}$ There is no significant increase in adipocyte number in short-term weight increase ${ }^{168}$ nor decrease following long-term weight loss. ${ }^{166}$

In individuals with obesity ${ }^{169}$ and individuals with type 2 diabetes, ${ }^{170}$ reduced generation of preadipocytes has been proposed, indicating defects in adipogenesis. In contrast, metabolically normal individuals with obesity have elevated levels of proadipogenic factors and lipid droplet proteins compared with metabolically compromised individuals. ${ }^{171}$ Adipose stem cells isolated from human subjects with obesity show reduced mitochondrial content, ability to proliferate, 

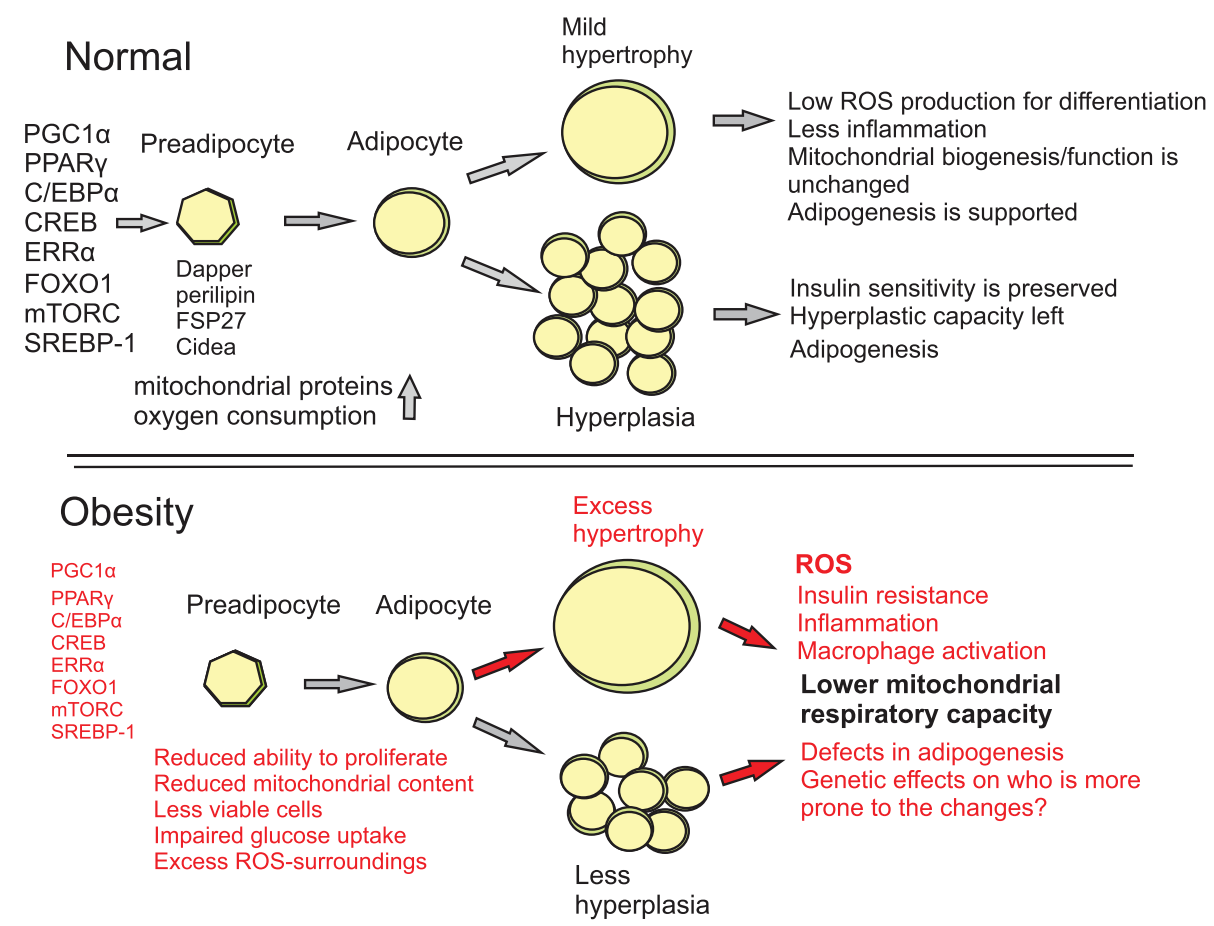

FIGURE 3 Adipogenesis, adipocyte hypertrophy and hyperplasia. The capacity of adipose tissue to enlarge is determined by the number of preadipocytes in the tissue and the capacity of preadipocytes to differentiate into adipocytes. Adipose tissue can enlarge by hypertrophy or hyperplasia. In normal state (above the line; black text, black arrows), nuclear transcripts induce preadipocyte recruitment and differentiation into adipocytes. Mitochondrial oxygen consumption and the amount of mitochondrial proteins increases. With increased fat mass, both hyperplasia and mild hypertrophy occur, preserving insulin sensitivity and mitochondrial function in the tissue. In obesity, excess FFAs stress the capacity of adipose tissue and its mitochondria. Nuclear transcripts inducing the differentiation of preadipocytes and mitochondrial function are downregulated (red text), leading to impaired differentiation and less mitochondria in the tissue (red). This in turn leads to less hyperplasia and increased hypertrophy of the cells (red arrows) leading to metabolic problems (red). However, some individuals with obesity appear to respond to increased FFA load more like in the normal state (black, above the line), with increased hyperplasia rather than only hypertrophy, avoiding part of the detrimental effects of fat accumulation. Mark explanations: red text, downregulated in obesity; black text, normal function; red arrows, metabolically unwanted changes; black arrows, normal function

and telomerase length and activity, and adipose stem cells in culture are less viable and more senescent than stem cells from lean persons. $^{172}$

Small adipocytes are generally regarded as metabolically healthier. Their proportion is increased for example in lean co-twins of obesitydiscordant twins, ${ }^{167}$ and smaller adipocytes have been reported in omental adipose tissue of individuals with morbid obesity but with preserved insulin sensitivity ${ }^{173}$ and in individuals characterized as "metabolically healthy" individuals with obesity, ${ }^{174}$ without features of metabolic syndrome. ${ }^{175}$ In contrast, an expanded population of small adipocytes and decreased expression of differentiation markers in the insulin-resistant versus insulin-sensitive individuals with obesity has been discovered, indicating potential defects in adipogenesis. ${ }^{176}$ Insulin stimulates adipocyte hypertrophy, ${ }^{177}$ but less hyperplasia. ${ }^{178}$ Thus, the authors proposed that insulin resistance may hinder the hypertrophic effects of insulin with an impaired adipocyte differentiation towards larger mature cells. ${ }^{176}$ However, based on the different studies, the insulin-sensitive persons with obesity, with a better adipocyte differentiation capacity, may be protected from the adverse effects of ectopic fat accumulation.

Arner et al have shown that subjects with a larger adipocyte volume than predicted for a given body fat mass (a hypertrophic adiposity phenotype) have lower rates of adipogenesis. ${ }^{179}$ In turn, high generation rates of adipocytes associate with a hyperplastic phenotype. ${ }^{179}$ After bariatric surgery, subjects with the hypertrophic obesity phenotype ${ }^{180}$ had the largest reductions in adipocyte size and gained most in insulin sensitivity. ${ }^{159}$ Interestingly, the adipocyte morphology in these latter studies was not associated with the amount of weight loss but rather to its metabolic outcomes indicating that the adipogenic capacity (regulated by mitochondria) of adipose tissue distinguishes the metabolic outcomes of obesity and of weight loss. However, both capacities-the hypertrophic and hyperplastic-seem to be needed for metabolic well-being.

We have previously associated large adipocyte volume to downregulation of mitochondria-related pathways in adipose tissue and these to the deterioration of metabolic profile in obesity. ${ }^{167}$ The "metabolically unhealthy" twins with increased liver fat content compared with their leaner co-twins had hypertrophied adipocytes and less hyperplasia in their subcutaneous adipose tissue, with downregulation of mitochondrial oxidative pathways. ${ }^{94}$ Our studies propose that some individuals may be able to respond to long-term energy excess with hyperplasia, while others predominantly react by hypertrophy, leading to differences in mitochondrial metabolism and the metabolic outcomes of obesity. A study by Yin et al in 2014 found reduced 
mitochondrial respiratory capacity in individuals with obesity compared with lean individuals, independent of adipocyte size. ${ }^{71}$ In 2015, Fisher et al also suggested that all adipocytes from an individual with obesity or from a lean individual have the same oxidative profile, independent of cell size, with obesity leading to impaired mitochondrial respiration in the cells. ${ }^{75}$ These findings support the idea that obesity leads to deterioration of adipose tissue hyperplastic capacity and mitochondrial function; the exact relationship of which still requires further study.

\subsection{0 | Visceral vs subcutaneous AT mitochondria}

The studies on mitochondria in humans are largely concentrated on findings in subcutaneous adipose tissue, probably due to its easier accessibility for studies.

The visceral adipocytes in normal-weight rats contain more mitochondria than subcutaneous adipocytes. ${ }^{181}$ In mice, subcutaneous adipocytes in turn seem to have a higher respiratory capacity than visceral adipocytes. ${ }^{67} \mathrm{~A}$ high-fat diet in mice decreased visceral adipocyte mitochondrial capacity more than that of subcutaneous adipocytes, with the development of glucose intolerance. ${ }^{67}$ In human studies, the mtDNA content in visceral adipose tissue was reduced in patients with diabetes but increased in patients with obesity compared with nonobese controls. ${ }^{72}$ Human subjects with obesity undergoing bariatric surgery had twice the concentration of mitochondria per mass of tissue in visceral versus subcutaneous fat, but visceral fat had smaller cells to make up the same mass. ${ }^{182}$ Respiration rates were higher in visceral than subcutaneous adipose tissue, but when normalized with mtDNA content, visceral adipose tissue had lower respiration per mitochondria and per adipocyte than subcutaneous adipose tissue. ${ }^{182}$

\subsection{1 | Mitochondrial oxidative metabolism and insulin sensitivity}

A link between adipocyte mitochondrial oxidative capacity and wholebody insulin sensitivity has been suggested by both rodent and human studies. ${ }^{183}$ Insulin-sensitive and insulin-resistant patients with obesity appear to differ in adipose tissue oxidative stress levels and in the expression of genes related to mitochondrial function, SIRT1/Nampt activity, ${ }^{111,173,184}$ and adipogenic capacity. ${ }^{94}$ In obesity-discordant twins, the "metabolically unhealthy" group presented with reduced expression of mitochondria-related pathways and reduced mtDNA amount in subcutaneous adipose tissue with increased inflammation and insulin resistance. ${ }^{94}$ These studies suggest an association between preserved mitochondrial function and insulin sensitivity.

More mechanistic studies in rodents reveal that excess glucose and fatty acids seem to lead to mitochondrial dysfunction. Mouse preadipocytes exposed to high glucose and fatty acids exhibit decreased mitochondrial size, decreased mitochondrial membrane potential, and downregulation of the master mitochondrial regulator PGC-1a. ${ }^{185}$ Impaired glucose homeostasis, decreased PGC-1a expression, and reduced mtDNA content in response to high-fat feeding have also been demonstrated in rats. ${ }^{186}$ High concentration of fatty acids in 3T3-L1 mouse adipocytes results in insulin resistance and in decreased levels of FoxO1, an inducer of adipogenesis and mitochondrial biogenesis. ${ }^{54}$

The mechanism linking mitochondrial dysfunction to the development of insulin resistance may involve the production of ROS. A highfat diet in mice increased mitochondrial ROS, which were shown to contribute to insulin resistance in adipose tissue, ${ }^{187}$ because genetic upregulation of the antioxidant enzyme MCAT was sufficient to reduce ROS damage and to preserve insulin signaling. ${ }^{187}$ In another mouse study, high-fat feeding resulted in increased ROS and mitochondrial oxygen consumption rate and subsequently insulin resistance, which later led to a reduction in mitochondrial biogenesis. ${ }^{188}$ Earlier studies have also linked the increase in oxidative radicals $\mathrm{O}_{2}$ superoxide and $\mathrm{H}_{2} \mathrm{O}_{2}$ to insulin resistance, ${ }^{187,189,190}$ and a long-term high-fat diet is associated with increased oxidative stress markers in humans and mice. ${ }^{191}$ A recent study on 3T3-L1 adipocytes and adipose tissue revealed a mechanism for the latter relationship, where elevated mitochondrial oxidants rapidly impair insulin-regulated GLUT4 translocation and lead to insulin resistance in tissue. ${ }^{192}$ Furthermore, another study in 3T3-L1 preadipocytes demonstrated that reduction in mtDNA levels and respiratory chain activity actually enhanced insulin signalling but nevertheless caused impaired insulin responsiveness by decreasing GLUT4 translocation on the cell surface. ${ }^{193}$

Taken together, these studies link mitochondrial oxidative activity and particularly ROS generated in the electron transport chain to insulin sensitivity. Excess fatty acids and glucose are the potential initiators of mitochondrial problems. This idea is in line with studies where lipid metabolites such as ceramide and diacylglyceroles (DAG) cause insulin resistance and impair mitochondrial function by activating serine kinases. ${ }^{194-196}$ Furthermore, interventions that have compromised mitochondrial function by genetic ${ }^{193}$ or pharmacologic ${ }^{197}$ mechanisms have resulted in insulin resistance.

The connection between mitochondrial respiratory activity to insulin resistance has not been replicable in all studies. A murine study found reduced mitochondrial parameters in both obese and diabetic mice ${ }^{60}$ and respiratory capacity in subcutaneous and visceral fat was reduced in obese mice, independent of insulin resistance. ${ }^{58}$ No connection between mitochondrial biogenesis and glucose homeostasis was observed in a study on mouse adipocytes ${ }^{198}$ and no association between type 2 diabetes and the activity of the mitochondrial OXPHOS complexes in human visceral adipose tissue. ${ }^{199}$

\subsection{2 | Mitochondrial oxidative metabolism and inflammation}

Inflammation is closely linked to adipose tissue dysfunction in obesity. Although downregulation of mitochondrial capacity and increased inflammation frequently co-occur in adipose tissue in obesity, ${ }^{62,94,95,200,201}$ the order of the events is not clear. Mitochondrial dysfunction can be both the cause and the consequence of 
inflammation. However, many studies suggest that mitochondrial dysfunction precedes inflammation in adipose tissue.

A study with diet-induced obese mice showed increased activity of pathways that favour fat storage and prevent lipid oxidation, with an early decrease in citrate synthase activity and expression of Pgc1a, with these changes preceding the inflammatory cell infiltration and the decrease in mitochondrial abundance. ${ }^{103}$ FFA and glucose in high quantities directly stimulate mitochondrial dysfunction ${ }^{185}$ and have led to high levels of TNFa, ER stress, and increased ROS 202,203 in mouse 3T3-L1 preadipocytes. The mechanisms by which mitochondrial dysfunction causes inflammation could include increased ROS production, which together with intermediary metabolic compounds ${ }^{204,205}$ predisposes to cell death and consequently to increased immune cell infiltration. ${ }^{206}$ Accumulation of intermediary metabolic compounds-protein carbonyls, lipid peroxidation products, and malondialdehyde-together with increased ROS production and mitochondrial oxidative stress has been observed in adipose tissue of subjects with obesity, with obesity and diabetes and non-obese subjects with diabetes compared with lean subjects. ${ }^{205}$ Expanding large adipocytes (with potential mitochondrial dysfunction) express inflammatory markers ${ }^{207,208}$ and release more chemokines ${ }^{207,208}$ and FFA, which are able to recruit macrophages into adipose tissue and activate inflammatory pathways. ${ }^{209}$ Furthermore, mitochondria synthesize phospholipids, which are responsible for the fluidity of the adipocyte cell membrane, ${ }^{210}$ and membrane lipid modifications in humans have been shown to recruit inflammatory cells into adipose tissue. ${ }^{211}$

Based on these studies, obesity may disrupt mitochondrial balance, leading to increased oxidative stress and increased inflammation in the adipose tissue. On the other hand, inflammation may lead to further deterioration of mitochondria-related metabolism in the cells, as evidenced by studies where preadipocytes obtained from mice ${ }^{212}$ or preadipocytes isolated from individuals with obesity ${ }^{213}$ have been treated with proinflammatory TNF-a. However, more studies are still needed on the exact causal relationship of mitochondrial dysfunction and inflammation in adipose tissue in obesity (Figure 4).

\subsection{3 | Methods to study mitochondria in adipose tissue}

There are many methods to study mitochondria. In this paragraph and in Table 1, we briefly summarize the main methods that have been used in white adipose tissue. On global level, the expression of genes related to mitochondria has been studied via transcriptomics from

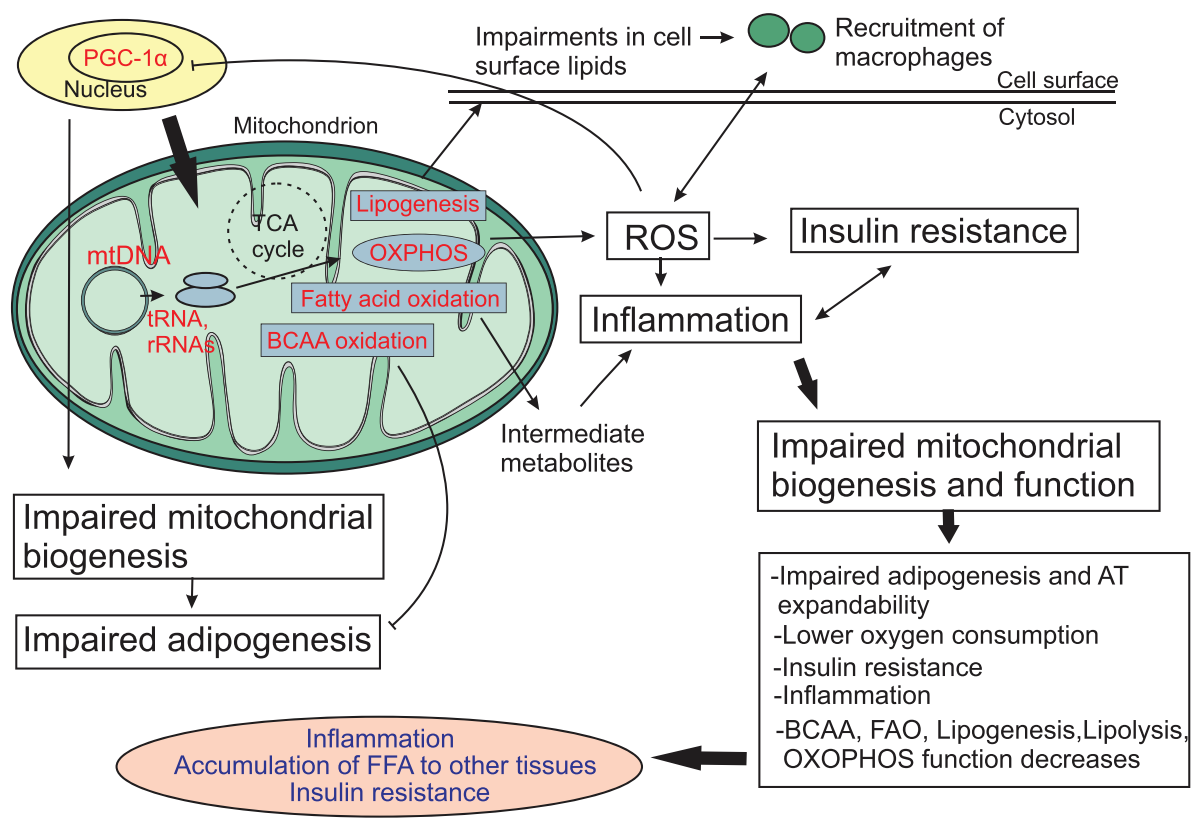

FIGURE 4 Mitochondrial dysfunction in relation to whole-body metabolism. In obesity, mitochondrial biogenesis and function with lipogenesis and lipolysis, oxidative phosphorylation, FFA oxidation and BCAA oxidation (main mitochondrial pathways, marked in red) appear to be impaired. Impaired mitochondrial biogenesis (an arrow from nucleus passing through mitochondria, presenting downregulation of mtDNA amount, mitochondrial mtRNAs and rRNAs, PGC-1a, OXPHOS subunits) is connected with impaired adipogenesis. Downregulation of BCAA oxidation also blocks the induction of adipogenesis by BCAA metabolites (a T-line BCAA-adipogenesis). Impaired OXPHOS produces excess ROS, leading to increased inflammation and insulin resistance in adipose tissue. ROS also activate the adipocytes to recruit macrophages into the tissue. Inflammation further impairs mitochondrial biogenesis. Changes in the generation of phospholipids for cell surface reduce the fluidity of the cell membrane and make the tissue more prone to inflammatory cell infiltration. These changes lead to impaired mitochondrial biogenesis and function (bold arrow). Mark explanations: red text, downregulated mitochondria-related transcripts or mitochondrial components in obesity; an arrow, induction; a T-line, inhibition; bolded arrows, main pathways leading to metabolic derangements. As a result, impaired adipogenesis, lower oxygen consumption of adipose tissue, increased insulin resistance and inflammation, and reduced oxidative and metabolic functions of adipose tissue are observed. These changes further connect with the accumulation of FFA to ectopic sites and internal organs, increased inflammation and insulin resistance in the whole-body level (oval, orange background) 


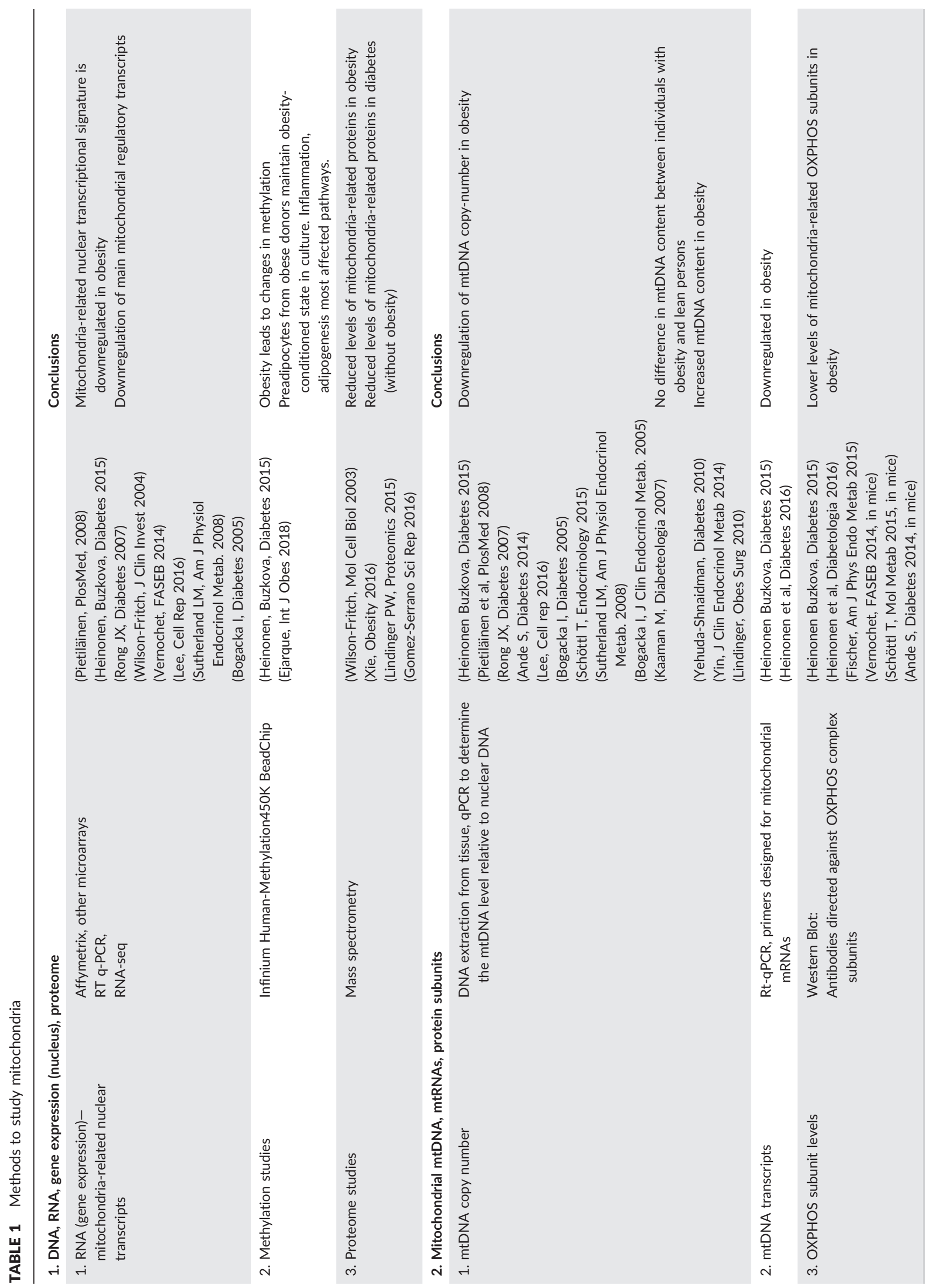




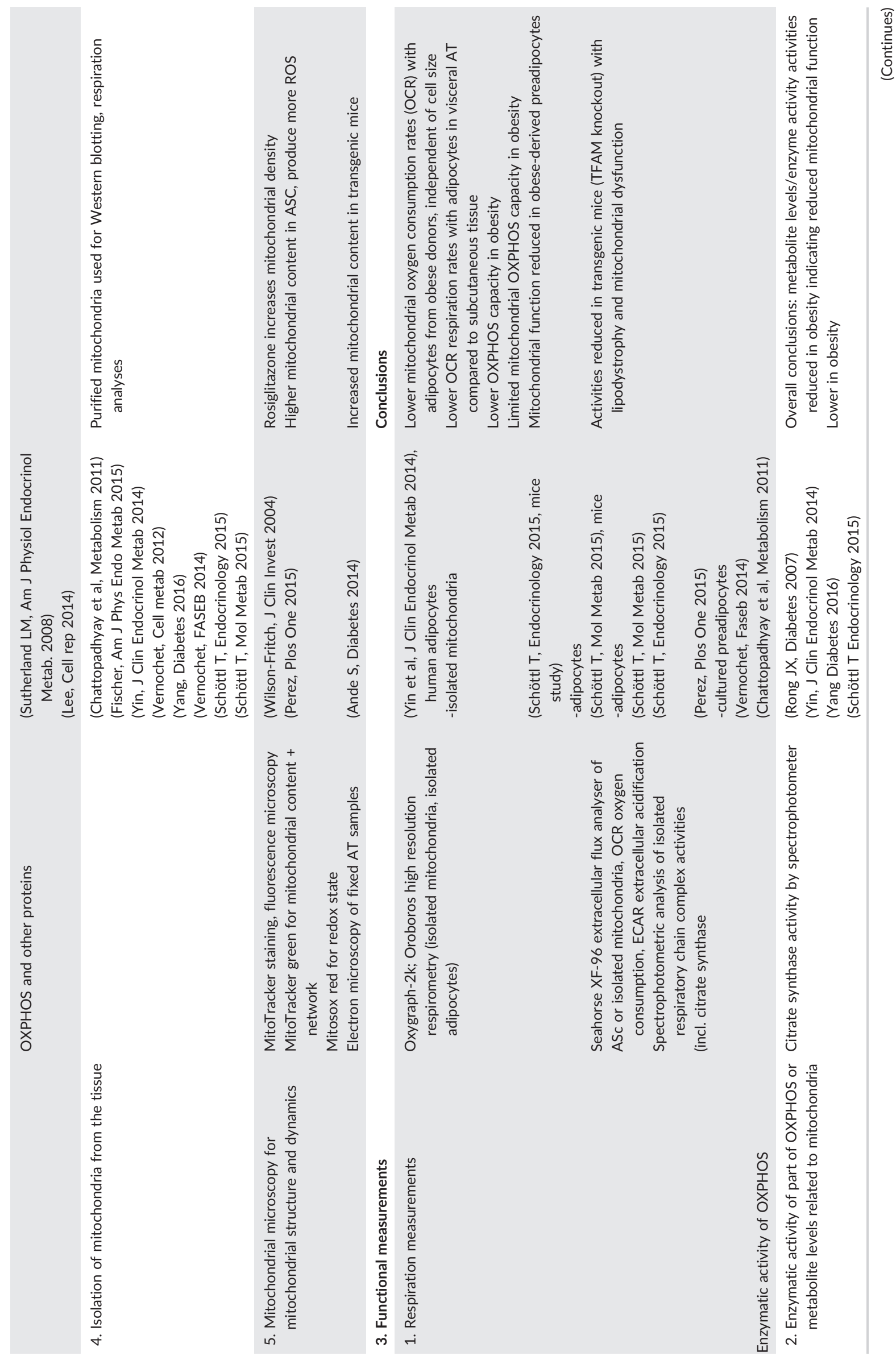


RNA isolated from adipose tissue or purified adipocytes. ${ }^{57,60-62,81,186}$ Mitocarta, a public inventory of 1158 human and mouse genes that encode proteins with strong support of mitochondrial localization, ${ }^{34}$ can help with finding the transcripts related to mitochondria. Similarly, proteomic studies by mass spectrometry determine the amount and distribution of mitochondria-related proteins of interest. ${ }^{77-79}$ Isolation of DNA and the epigenetic studies has been used to determining the activity or silencing via methylation of certain mitochondria-related genes. $^{62,76}$

More targeted analyses can be made from mitochondria isolated from the tissue. ${ }^{71,74,75}$ The mtDNA copy number in mitochondria by qPCR may be determined by specifically targeted primers to evaluate the mitochondrial DNA amount relative to nuclear DNA. ${ }^{61,62,65,67,186}$ As mitochondria may possess multiple copies of their genome, mtDNA mass does not equal the number of mitochondria in the tissue. The transcript levels of the mtDNA encoded genes can be studied by mtRNA targeted quantitative RT-PCRprimers. ${ }^{62,63}$ The levels of mitochondria-encoded protein subunits of the OXPHOS complexes by western blot may be determined. ${ }^{58,62,63,75,81}$ Immunoblotting can be used to study the levels of also other specific nuclear-encoded mitochondria-related proteins. ${ }^{58,69,81,186}$

Mitochondrial staining by MitoTracker Green or other mitochondrial dyes for fluorescence microscopy determinations add to the knowledge on mitochondrial morphology and distribution $57,58,69,81$ The ultrastructure of mitochondria have been further studied with transmission electron microscopy. ${ }^{69}$

Studies assessing mitochondrial function directly in adipose tissue or preadipocytes include respiration capacity measurements of preadipocyte cultures or isolated mitochondria by Seahorse extracellular flux analyzer ${ }^{58,172}$ or respirometry analyses from isolated mitochondria or adipocytes by Oroboros $\mathrm{O} 2 \mathrm{~K}$ high-resolution respirometry. ${ }^{58,67,71}$ Spectrophotometric analyses of isolated respiratory chain complex activities have also been used to assess OXPHOS activity. ${ }^{74,81}$ Also, single enzyme activities in pathways other than OXPHOS, such as citrate synthase activity, ${ }^{58,60,67,71}$ have been used as an indicator of mitochondrial activity.

Indirect ways of studying mitochondria include methods, where the oxygen consumption of the tissues is calculated through measuring blood flow in the tissue, ${ }^{111,112}$ through the inorganic phosphate utilization of mitochondria ${ }^{74}$ or other metabolites entering and formed in adipose tissue or cultured preadipocytes by spectrophotometric assays: ATP content, ${ }^{80}$ fumarate, succinate, ${ }^{185}$ or other mitochondria-related metabolites.

\subsection{4 | Interventions to enhance mitochondrial biogenesis in AT}

Enhancing mitochondrial amount or function in adipose tissue may help with addressing the metabolic complications of obesity.

Some pharmacological interventions that have already been tested to treat insulin resistance could increase mitochondrial biogenesis in obesity. PPARY-agonist thiazolidinediones (TZDs) have 
been used to treat patients with type 2 diabetes. These agents improve the insulin sensitivity of adipose and other tissues. TZDs appear to increase mitochondrial biogenesis, function, and content. They improve oxidative capacity in adipocytes in mice and upregulate mitochondria-associated genes, mtDNA amount, and PGC$1 a^{57,149}$ In humans, evidence of this has also been shown in vitro ${ }^{214}$ and in vivo, where treatment with pioglitazone improved mitochondrial biogenesis in patients with diabetes by stimulating the expression of genes important for fatty acid oxidation and PGC-1a and by increasing mitochondrial copy number. ${ }^{66}$ However, rosiglitazone from the same TZD group caused cardiovascular problems, which led to its withdrawal from use. ${ }^{215,216}$ In humans, treatment with vitamin $D^{217}$ reduced oxidative stress and improved insulin sensitivity. Vitamin E in mice activated PPARalpha, the mediator of mitochondrial fatty acid oxidation, and improved insulin sensitivity. $^{218}$ R-alpha-lipoic acid and acetyl-L-carnitine enhanced mitochondrial biogenesis and fatty-acid oxidation in cultured mouse adipocytes. $^{219}$ The same compounds have resulted in improvement in insulin sensitivity in human studies, although no relation to mitochondria was studied. 220,221 However, other human studies have failed to show the association between antioxidants and improved metabolism. ${ }^{222,223}$ Chemical uncouplers that dissipate the energy produced by mitochondria as heat have led to weight loss ${ }^{224}$ but also to uncontrolled thermogenesis with fatal increases in body temperature. $^{225}$ Use of chemical uncouplers has thus discontinued. In muscle studies, exercise 226,227 (with PGC-1a and VEGFA upregulation $^{228}$ ) and caloric restriction in muscle and adipose tissue (AMPK and SIRT1 as the principal modulators ${ }^{229,230}$ ) appear to improve mitochondrial biogenesis. However, data from adipose tissue are still sparse. In mouse studies, resveratrol and other small-molecule compounds that activate SIRT1 have led to improvement in insulin sensitivity in adipose tissue, muscle, and liver ${ }^{231,232}$ and increased the expression of mitochondria-related genes in liver and muscle tissue. $^{232}$

Bariatric surgery has also emerged as a possibility to improve metabolic health in obesity. After surgery, insulin-resistant individuals exhibit increased levels of mitofilin (a regulator of mitochondrial membrane architecture), increased PGC-1a protein levels, and upregulation of mitochondrial superoxide dismutase. ${ }^{233}$ In normoglycaemic individuals, mitofilin and PGC-1a were already high before bariatric surgery and decreased afterwards. ${ }^{233}$ Bariatric surgery may thus enhance mitochondrial biogenesis, activity, and antioxidant defences in adipose tissue of insulin-resistant subjects with obesity, but more studies on this are still needed.

Obesity is a multisystemic and multifactorial disease. Personalized therapies will be needed to treat individuals with obesity with different metabolic status and to administer drugs locally. ${ }^{234}$ Targeting mitochondrial metabolism may decrease insulin resistance and inflammation and enhance preadipocyte differentiation in adipose tissue with beneficial effects in the treatment of obesity. Targeted antioxidant supplements, mild and safe mitochondrial uncoupling agents with thiazolidinedione-type drugs, or both may be beneficial.

\section{5 | CONCLUSIONS}

Normal mitochondrial function has central effects on the health and function of adipose tissue. The downregulation of mitochondrial oxidative metabolism in obesity has been shown in many animal and human studies, involving both adipose tissue and adipocytes, with changes in gene expression as well as in the methylation pattern of the cells. Disruptions in adipocyte mitochondrial function and increased demand for FFA and glucose disposal in obesity lead to enhanced lipid deposition in the cell. ${ }^{145}$ This may lead to enhanced stress, accumulation of intermediary metabolites, increased inflammation and ROS, and reduced mitochondrial biogenesis. This can further lead to reduction in adipogenesis, oxidative metabolism, and insulin sensitivity of the cells, ${ }^{2,4}$ as well as to inflammation. If adipose tissue and its mitochondria are dysfunctional and the storage capacity of adipocytes is compromised, FFA spill over to ectopic sites in the liver, muscle, and pancreas causing dysfunction and insulin resistance. ${ }^{235}$ Mitochondrial dysfunction also reduces the synthesis of adiponectin. ${ }^{137-139}$ Adipose tissue dysfunction has been recognized as an important contributor to obesity-related disorders ${ }^{5,6}$ and can increase the risk of developing insulin resistance and metabolic complications of obesity. ${ }^{9,236}$ In the light of these findings, it seems plausible to suggest mitochondria as one of the underlying causes behind the metabolic complications that develop during obesity. (Figure 4)

Based on current knowledge, there is a widespread downregulation of adipose tissue mitochondria in obesity, although with some controversy on the causal relationships between low mitochondrial oxidative function with inflammation, insulin resistance, and deranged differentiation of cells. These aspects require more follow-up studies in humans. Downregulation of mitochondrial function or biogenesis in obesity has long-term consequences for the metabolism of adipose tissue and the whole body. (Figure 4)

Future research on understanding the exact pathways that lead to mitochondrial dysfunction in adipose tissue in obesity and revealing possible targets for pharmacological or nutritional interventions to enhance mitochondrial biogenesis or function in obesity is warranted. Distinguishing the individuals most prone to the metabolic problems of obesity and who would gain most of the interventions will be an important future target. ${ }^{62,94}$ More mechanistical studies are needed on the relationship of mitochondrial function, inflammation, and insulin resistance to be able to answer this need.

Mitochondria in white adipose tissue may in future be pharmacologically modified to enhance their function and amount and provide metabolic benefits for people with obesity. Compounds already identified for this purpose include agonists for the PPARs and ERRs, SIRT1, TGR5, and AMPK. ${ }^{237}$ However, these compounds only target one specific site in a complex network, and thus, compounds with a broader effect, targeting many dysfunctional sites, should be identified with computer-based methods. ${ }^{237}$ These compounds can include ones that restore mitochondrial function and also those that are toxic to mitochondria and should be avoided. ${ }^{237}$

Specific diets to promote mitochondrial function may be studied. The types and amount of exercise to elicit best benefits for adipose 
tissue mitochondria may be investigated. ${ }^{238}$ Imitating interventions like bariatric surgery that seem to preserve a favourable metabolic profile in adipose tissue should be investigated further. Combining different strategies will be a key issue in combating a multifactorial disease like obesity.

\section{FUNDING}

The study was supported by Helsinki University Hospital Research Funds (KHP) and grants from the Novo Nordisk Foundation (KHP), Finnish Diabetes Research Foundation (SH and KHP), Gyllenberg Foundation (KHP), Jalmari and Rauha Ahokas Foundation (KHP), Finnish Foundation for Cardiovascular Research (KHP), Academy of Finland (272376, 266286, and 314383 for KHP), Emil Aaltonen Foundation (SH), Finnish Medical Foundation (SH and KHP), the Finnish Cultural Foundation (RJ), University of Helsinki (KHP), Helsinki University Central Hospital (KHP), and Finnish Government Research Funds (KHP).

\section{CONFLICT OF INTEREST}

The manuscript has been accepted by all co-authors; all had access to the materials and data and hold the final responsibility for the submission of the article. We state that the study is original, has not been submitted for publication in other journals, and has not yet been published either whole or in part. The authors declare no conflicts of interest with this article.

\section{AUTHOR CONTRIBUTIONS}

$\mathrm{SH}$ wrote the manuscript. RJ, KHP, and AR participated in the writing and KHP, RJ, and AR in the revision of the work. KHP designed the research and supervised the work. KHP is the guarantor of this work and as such had full access to the data and takes responsibility for the integrity of the data.

\section{ORCID}

Sini Heinonen (1) https://orcid.org/0000-0002-6342-0577

\section{REFERENCES}

1. Greenberg AS, Obin MS. Obesity and the role of adipose tissue in inflammation and metabolism. Am J Clin Nutr. 2006;83 (2):461S-465S. http://ovidsp.ovid.com/ovidweb.cgi?T=JS\&CSC= $Y \& N E W S=N \& P A G E=$ fulltext\&D=med5\&AN $=16470013$

2. Heilbronn L, Smith SR, Ravussin E. Failure of fat cell proliferation, mitochondrial function and fat oxidation results in ectopic fat storage, insulin resistance and type II diabetes mellitus. Int J Obes Relat Metab Disord J Int Assoc Study Obes. 2004;28(Suppl 4):S12-S21. http:// ovidsp.ovid.com/ovidweb.cgi?T=JS\&CSC=Y\&NEWS=N\&PAGE= fulltext\&D=med5\&AN=15592481

3. De Pauw A, Tejerina S, Raes M, Keijer J, Arnould T. Mitochondrial (dys)function in adipocyte (de)differentiation and systemic metabolic alterations. Am J Pathol. 2009;175(3):927-939. https://doi.org/ 10.2353/ajpath.2009.081155

4. Kusminski CM, Scherer PE. Mitochondrial dysfunction in white adipose tissue. Trends Endocrinol Metab. 2012;23(9):435-443. https:// doi.org/10.1016/j.tem.2012.06.004
5. Goossens $\mathrm{GH}$. The role of adipose tissue dysfunction in the pathogenesis of obesity-related insulin resistance. Physiol Behav. 2008;94 (2):206-218. http://ovidsp.ovid.com/ovidweb.cgi?T=JS\&CSC= $Y \& N E W S=N \& P A G E=$ fulltext\&D=med5\&AN=18037457

6. Rosen ED, Spiegelman BM. What we talk about when we talk about fat. Cell. 2014;156(1-2):20-44. https://doi.org/10.1016/j. cell.2013.12.012

7. Hausman DB, DiGirolamo M, Bartness TJ, Hausman GJ, Martin RJ. The biology of white adipocyte proliferation. Obes Rev. 2001;2 (4):239-254. http://ovidsp.ovid.com/ovidweb.cgi?T=JS\&CSC= $Y \& N E W S=N \& P A G E=$ fulltext\&D=med4\&AN $=12119995$

8. Ravussin E, Smith SR. Increased fat intake, impaired fat oxidation, and failure of fat cell proliferation result in ectopic fat storage, insulin resistance, and type 2 diabetes mellitus. Ann N Y Acad Sci. 2002;967:363-378. http://ovidsp.ovid.com/ovidweb.cgi?T=JS\&CSC= $Y \& N E W S=N \& P A G E=$ fulltext\&D=med4\&AN=12079864

9. Hajer GR, van Haeften TW, Visseren FLJ. Adipose tissue dysfunction in obesity, diabetes, and vascular diseases. Eur Heart J. 2008;29 (24):2959-2971. https://doi.org/10.1093/eurheartj/ehn387

10. Sun K, Kusminski CM, Scherer PE. Adipose tissue remodeling and obesity. J Clin Invest. 2011;121(6):2094-2101. https://doi.org/ $10.1172 / \mathrm{JCl} 45887$

11. Fruhbeck G. Overview of adipose tissue and its role in obesity and metabolic disorders. Methods Mol Biol. 2008;456:1-22. https://doi. org/10.1007/978-1-59745-245-8_1

12. Curat CA, Miranville A, Sengenes $C$, et al. From blood monocytes to adipose tissue-resident macrophages: induction of diapedesis by human mature adipocytes. Diabetes. 2004;53(5):1285-1292. http:// ovidsp.ovid.com/ovidweb.cgi?T=JS\&CSC $=Y \& N E W S=N \& P A G E=$ fulltext\&D=med5\&AN=15111498

13. Wajchenberg BL. Subcutaneous and visceral adipose tissue: their relation to the metabolic syndrome. Endocr Rev. 2000;21(6):697-738. http://ovidsp.ovid.com/ovidweb.cgi? $T=J S \& C S C=Y \& N E W S=$ $N \& P A G E=$ fulltext\&D=med4\&AN=11133069

14. Arner P. Regional adipocity in man. J Endocrinol. 1997;155 (2):191-192. http://ovidsp.ovid.com/ovidweb.cgi?T=JS\&CSC= $Y \& N E W S=N \& P A G E=$ fulltext $\& D=$ med $4 \& A N=9415044$

15. Pellegrinelli V, Carobbio S, Vidal-Puig A. Adipose tissue plasticity: how fat depots respond differently to pathophysiological cues. Diabetologia. 2016;59(6):1075-1088. https://doi.org/10.1007/ s00125-016-3933-4

16. Lee M-J, Wu Y, Fried SK. Adipose tissue heterogeneity: implication of depot differences in adipose tissue for obesity complications. Mol Aspects Med. 2013;34(1):1-11. https://doi.org/10.1016/j.mam.2012. 10.001

17. Giralt M, Villarroya F. White, brown, beige/brite: different adipose cells for different functions? Endocrinology. 2013;154(9):2992-3000. https://doi.org/10.1210/en.2013-1403

18. Cannon B, Nedergaard J. Brown adipose tissue: function and physiological significance. Physiol Rev. 2004;84(1):277-359.

19. Virtanen KA, Orava J, Savisto N-J, et al. Functional brown adipose tissue in healthy adults. N Engl J Med. 2009;360(15):1518-1525. https://doi.org/10.1056/NEJMoa0808949

20. Oelkrug R, Polymeropoulos ET, Jastroch M. Brown adipose tissue: physiological function and evolutionary significance. J Comp Physiol B. 2015;185(6):587-606. https://doi.org/10.1007/s00360-015-0907-7

21. Saito M, Okamatsu-Ogura Y, Matsushita M, et al. High Incidence of Metabolically Active Brown Adipose Tissue in Healthy Adult Humans. Diabetes. 2009;58(7):1526-1531. https://doi.org/10.2337/DB090530 
22. van Marken Lichtenbelt WD, Vanhommerig JW, Smulders NM, et al. Cold-Activated Brown Adipose Tissue in Healthy Men. $N$ Engl J Med. 2009;360(15):1500-1508. https://doi.org/10.1056/ nejmoa0808718

23. Orava J, Nuutila P, Noponen $\mathrm{T}$, et al. Blunted metabolic responses to cold and insulin stimulation in brown adipose tissue of obese humans. Obesity (Silver Spring). 2013;21(11):2279-2287. https://doi.org/ 10.1002/oby. 20456

24. Blondin DP, Labbé SM, Tingelstad HC, et al. Increased brown adipose tissue oxidative capacity in cold-acclimated humans. J Clin Endocrinol Metab. 2014;99(3):E438-E446. https://doi.org/10.1210/jc.20133901

25. Kopecký J, Hodný Z, Rossmeisl M, Syrový I, Kozak LP. Reduction of dietary obesity in aP2-Ucp transgenic mice: physiology and adipose tissue distribution. Am J Physiol. 1996;270(5 Pt 1):E768-E775. https://doi.org/10.1152/ajpendo.1996.270.5.E768

26. Vitali A, Murano I, Zingaretti MC, Frontini A, Ricquier D, Cinti S. The adipose organ of obesity-prone $\mathrm{C} 57 \mathrm{BL} / 6 \mathrm{~J}$ mice is composed of mixed white and brown adipocytes. J Lipid Res. 2012;53(4):619-629. https://doi.org/10.1194/jlr.M018846

27. Carpentier AC, Blondin DP, Virtanen KA, Richard D, Haman F, Turcotte ÉE. Brown Adipose Tissue Energy Metabolism in Humans. Front Endocrinol (Lausanne). 2018;9:447. https://doi.org/10.3389/ fendo.2018.00447

28. Trayhurn P. Brown Adipose Tissue-A Therapeutic Target in Obesity? Front Physiol. 2018;9:1672. https://doi.org/10.3389/fphys.2018. 01672

29. Bartelt A, Heeren J. Adipose tissue browning and metabolic health. Nat Rev Endocrinol. 2014;10(1):24-36. https://doi.org/10.1038/ nrendo.2013.204

30. Boudina S, Graham TE. Mitochondrial function/dysfunction in white adipose tissue. Exp Physiol. 2014;99(9):1168-1178. https://doi.org/ 10.1113/expphysiol.2014.081414

31. O'Brien TW. Properties of human mitochondrial ribosomes. IUBMB Life. 2003;55(9):505-513. http://ovidsp.ovid.com/ovidweb.cgi?T= $J S \& C S C=Y \& N E W S=N \& P A G E=$ fulltext\&D=med4\&AN=14658756

32. Falkenberg M, Larsson NG, Gustafsson CM. DNA replication and transcription in mammalian mitochondria. Annu Rev Biochem. 2007;76:679-699. http://ovidsp.ovid.com/ovidweb.cgi?T=JS\&CSC= $Y \& N E W S=N \& P A G E=$ fulltext\&D=med5\&AN=17408359

33. Pagliarini DJ, Calvo SE, Chang B, et al. A mitochondrial protein compendium elucidates complex I disease biology. Cell. 2008;134 (1):112-123. https://doi.org/10.1016/j.cell.2008.06.016

34. Calvo SE, Clauser KR, Mootha VK. MitoCarta2.0: an updated inventory of mammalian mitochondrial proteins. Nucleic Acids Res. 2016;44(D1):D1251-D1257. https://doi.org/10.1093/nar/gkv1003

35. Goldenthal MJ, Marin-Garcia J. Mitochondrial signaling pathways: a receiver/integrator organelle. Mol Cell Biochem. 2004;262(1-2):1-16. http://ovidsp.ovid.com/ovidweb.cgi?T=JS\&CSC $=$ Y\&NEWS $=$ $N \& P A G E=$ fulltext $\& D=$ med $5 \& A N=15532704$

36. Neupert W, Herrmann JM. Translocation of proteins into mitochondria. Annu Rev Biochem. 2007;76:723-749. http://ovidsp.ovid.com/ ovidweb.cgi?T=JS\&CSC=Y\&NEWS=N\&PAGE=fulltext\&D= med5\&AN=17263664

37. McGarry JD, Brown NF. The mitochondrial carnitine palmitoyltransferase system. From concept to molecular analysis. Eur J Biochem. 1997;244(1):1-14. http://ovidsp.ovid.com/ovidweb.cgi?T= $J S \& C S C=Y \& N E W S=N \& P A G E=$ fulltext $\& D=$ med $4 \& A N=9063439$

38. Hutson $S M$, Wallin R, Hall TR. Identification of mitochondrial branched chain aminotransferase and its isoforms in rat tissues. $J$ Biol
Chem. 1992;267(22):15681-15686. http://ovidsp.ovid.com/ovidweb. cgi? $T=J S \& C S C=Y \& N E W S=N \& P A G E=$ fulltext $\& D=$ med $3 \& A N=$ 1639805

39. Gao AW, Canto C, Houtkooper RH. Mitochondrial response to nutrient availability and its role in metabolic disease. EMBO Mol Med. 2014;6(5):580-589. https://doi.org/10.1002/emmm.201303782

40. Detmer SA, Chan DC. Functions and dysfunctions of mitochondrial dynamics. Nat Rev Mol Cell Biol. 2007;8(11):870-879. http://ovidsp. ovid.com/ovidweb.cgi? $T=J S \& C S C=Y \& N E W S=N \& P A G E=$ fulltext\&D= med5\&AN=17928812

41. Frazier AE, Kiu C, Stojanovski D, Hoogenraad NJ, Ryan MT. Mitochondrial morphology and distribution in mammalian cells. Biol Chem. 2006;387(12):1551-1558. http://ovidsp.ovid.com/ovidweb. cgi $? \mathrm{~T}=\mathrm{JS} \& C S C=\mathrm{Y} \& N E W S=N \& P A G E=$ fulltext $\& D=$ med $5 \& A N=$ 17132100

42. Tol MJ, Ottenhoff R, van Eijk M, et al. A PPARy-Bnip3 Axis Couples Adipose Mitochondrial Fusion-Fission Balance to Systemic Insulin Sensitivity. Diabetes. 2016;65(9):2591-2605. https://doi.org/ 10.2337/db16-0243

43. Jheng H-F, Tsai P-J, Guo S-M, et al. Mitochondrial fission contributes to mitochondrial dysfunction and insulin resistance in skeletal muscle. Mol Cell Biol. 2012;32(2):309-319. https://doi.org/10.1128/ MCB.05603-11

44. Mihaylova MM, Shaw RJ. The AMPK signalling pathway coordinates cell growth, autophagy and metabolism. Nat Cell Biol. 2011;13 (9):1016-1023. https://doi.org/10.1038/ncb2329

45. Hardie DG. AMP-activated protein kinase: an energy sensor that regulates all aspects of cell function. Genes Dev. 2011;25(18):1895-1908. https://doi.org/10.1101/gad.17420111

46. Handschin C, Spiegelman BM. Peroxisome proliferator-activated receptor gamma coactivator 1 coactivators, energy homeostasis, and metabolism. Endocr Rev. 2006;27(7):728-735. http://ovidsp.ovid. com/ovidweb.cgi?T=JS\&CSC $=Y \& N E W S=N \& P A G E=$ fulltext\&D= med5\&AN=17018837

47. Scarpulla RC. Metabolic control of mitochondrial biogenesis through the PGC-1 family regulatory network. Biochim Biophys Acta. 2011;1813(7):1269-1278. https://doi.org/10.1016/j.bbamcr.2010. 09.019

48. Houtkooper RH, Canto C, Wanders RJ, Auwerx J. The secret life of NAD+: an old metabolite controlling new metabolic signaling pathways. Endocr Rev. 2010;31(2):194-223. https://doi.org/10.1210/ er.2009-0026

49. Schreiber SN, Emter R, Hock MB, et al. The estrogen-related receptor alpha (ERRalpha) functions in PPARgamma coactivator 1alpha (PGC1alpha)-induced mitochondrial biogenesis. Proc Natl Acad Sci U S A. 2004;101(17):6472-6477. http://ovidsp.ovid.com/ovidweb.cgi?T= $J S \& C S C=Y \& N E W S=N \& P A G E=$ fulltext $\& D=\operatorname{med} 5 \& A N=15087503$

50. Mootha VK, Handschin C, Arlow D, et al. Erralpha and Gabpa/b specify PGC-1alpha-dependent oxidative phosphorylation gene expression that is altered in diabetic muscle. Proc Natl Acad Sci U S A. 2004;101(17):6570-6575. http://ovidsp.ovid.com/ovidweb.cgi?T= $J S \& C S C=Y \& N E W S=N \& P A G E=$ fulltext $\& D=$ med $5 \& A N=15100410$

51. Wu Z, Puigserver $P$, Andersson $U$, et al. Mechanisms controlling mitochondrial biogenesis and respiration through the thermogenic coactivator PGC-1. Cell. 1999;98(1):115-124. http://ovidsp.ovid. com/ovidweb.cgi?T=JS\&CSC=Y\&NEWS=N\&PAGE=fulltext\&D= med4\&AN=10412986

52. Virbasius JV, Scarpulla RC. Activation of the human mitochondrial transcription factor A gene by nuclear respiratory factors: a potential regulatory link between nuclear and mitochondrial gene expression in organelle biogenesis. Proc Natl Acad Sci U S A. 1994;91(4):1309-1313. 
http://ovidsp.ovid.com/ovidweb.cgi?T=JS\&CSC=Y\&NEWS= $N \& P A G E=$ fulltext\&D=med $3 \& A N=8108407$

53. Munekata K, Sakamoto K. Forkhead transcription factor Foxo1 is essential for adipocyte differentiation. In Vitro Cell Dev Biol Anim. 2009;45(10):642-651. https://doi.org/10.1007/s11626-009-9230-5

54. Subauste AR, Burant CF. Role of FoxO1 in FFA-induced oxidative stress in adipocytes. Am J Physiol Endocrinol Metab. 2007;293(1): E159-E164. https://doi.org/10.1152/ajpendo.00629.2006

55. Mechta M, Ingerslev LR, Fabre O, Picard M, Barrès R. Evidence Suggesting Absence of Mitochondrial DNA Methylation. Front Genet. 2017;8:166. https://doi.org/10.3389/fgene.2017.00166

56. Matsuda S, Yasukawa T, Sakaguchi Y, et al. Accurate estimation of 5-methylcytosine in mammalian mitochondrial DNA. Sci Rep. 2018;8 (1):5801-5813. https://doi.org/10.1038/s41598-018-24251-z

57. Wilson-Fritch L, Nicoloro S, Chouinard M, et al. Mitochondrial remodeling in adipose tissue associated with obesity and treatment with rosiglitazone. J Clin Invest. 2004;114(9):1281-1289. http://ovidsp. ovid.com/ovidweb.cgi?T=JS\&CSC $=Y \& N E W S=N \& P A G E=$ fulltext\&D= med5\&AN=15520860

58. Schottl T, Kappler L, Fromme T, Klingenspor M. Limited OXPHOS capacity in white adipocytes is a hallmark of obesity in laboratory mice irrespective of the glucose tolerance status. Mol Metab. 2015;4 (9):631-642. https://doi.org/10.1016/j.molmet.2015.07.001

59. Choo H-J, Kim J-H, Kwon O-B, et al. Mitochondria are impaired in the adipocytes of type 2 diabetic mice. Diabetologia. 2006;49 (4):784-791. http://ovidsp.ovid.com/ovidweb.cgi?T=JS\&CSC= $Y \& N E W S=N \& P A G E=$ fulltext\&D=med5\&AN $=16501941$

60. Rong JX, Qiu Y, Hansen MK, et al. Adipose mitochondrial biogenesis is suppressed in $\mathrm{db} / \mathrm{db}$ and high-fat diet-fed mice and improved by rosiglitazone. Diabetes. 2007;56(7):1751-1760. http://ovidsp.ovid. com/ovidweb.cgi?T=JS\&CSC=Y\&NEWS=N\&PAGE=fulltext\&D= med5\&AN=17456854

61. Pietilainen $\mathrm{KH}$, Naukkarinen J, Rissanen A, et al. Global transcript profiles of fat in monozygotic twins discordant for BMI: pathways behind acquired obesity. PLoS Med. 2008;5(3):e51. https://doi.org/10.1371/ journal.pmed.0050051

62. Heinonen S, Buzkova J, Muniandy M, et al. Impaired Mitochondrial Biogenesis in Adipose Tissue in Acquired Obesity. Diabetes. 2015;64 (9):3135-3145. https://doi.org/10.2337/db14-1937

63. Heinonen S, Muniandy M, Buzkova J, et al. Mitochondria-related transcriptional signature is downregulated in adipocytes in obesity: a study of young healthy MZ twins. Diabetologia. 2017;60(1):169-181. https://doi.org/10.1007/s00125-016-4121-2

64. Pietiläinen $\mathrm{KH}$, Ismail $\mathrm{K}$, Järvinen $\mathrm{E}$, et al. DNA methylation and gene expression patterns in adipose tissue differ significantly within young adult monozygotic BMl-discordant twin pairs. Int J Obes (Lond). 2016;40(4):654-661. https://doi.org/10.1038/ijo.2015.221

65. Kaaman M, Sparks LM, van Harmelen V, et al. Strong association between mitochondrial DNA copy number and lipogenesis in human white adipose tissue. Diabetologia. 2007;50(12):2526-2533. http:// ovidsp.ovid.com/ovidweb.cgi?T=JS\&CSC=Y\&NEWS=N\&PAGE= fulltext\&D=med5\&AN=17879081

66. Bogacka I, Xie H, Bray GA, Smith SR. Pioglitazone induces mitochondrial biogenesis in human subcutaneous adipose tissue in vivo. Diabetes. 2005;54(5):1392-1399. http://ovidsp.ovid.com/ovidweb. cgi? $T=J S \& C S C=Y \& N E W S=N \& P A G E=$ fulltext $\& D=\operatorname{med} 5 \& A N=$ 15855325

67. Schöttl T, Kappler L, Braun K, Fromme T, Klingenspor M. Limited Mitochondrial Capacity of Visceral Versus Subcutaneous White Adipocytes in Male C57BL/6N Mice. Endocrinology. 2015;156(3): 923-933. https://doi.org/10.1210/en.2014-1689
68. Yang R, Barouch LA. Leptin signaling and obesity: cardiovascular consequences. Circ Res. 2007;101(6):545-559. http://ovidsp.ovid.com/ ovidweb.cgi?T=JS\&CSC=Y\&NEWS=N\&PAGE=fulltext\&D= med5\&AN=17872473

69. Ande SR, Nguyen KH, Padilla-Meier GP, Wahida W, Nyomba BLG, Mishra S. Prohibitin overexpression in adipocytes induces mitochondrial biogenesis, leads to obesity development, and affects glucose homeostasis in a sex-specific manner. Diabetes. 2014;63 (11):3734-3741. https://doi.org/10.2337/db13-1807

70. Yehuda-Shnaidman E, Buehrer B, Pi J, Kumar N, Collins S. Acute stimulation of white adipocyte respiration by PKA-induced lipolysis. Diabetes. 2010;59(10):2474-2483. https://doi.org/10.2337/db100245

71. Yin X, Lanza IR, Swain JM, Sarr MG, Nair KS, Jensen MD. Adipocyte mitochondrial function is reduced in human obesity independent of fat cell size. J Clin Endocrinol Metab. 2014;99(2):E209-E216. https:// doi.org/10.1210/jc.2013-3042

72. Lindinger A, Peterli R, Peters T, et al. Mitochondrial DNA content in human omental adipose tissue. Obes Surg. 2010;20(1):84-92. https://doi.org/10.1007/s11695-009-9987-3

73. Semple RK, Crowley VC, Sewter CP, et al. Expression of the thermogenic nuclear hormone receptor coactivator PGC-1alpha is reduced in the adipose tissue of morbidly obese subjects. Int J Obes Relat Metab Disord J Int Assoc Study Obes. 2004;28(1):176-179. http://ovidsp. ovid.com/ovidweb.cgi?T=JS\&CSC=Y\&NEWS=N\&PAGE=fulltext\&D= medc\&AN=14557831

74. Chattopadhyay M, Guhathakurta I, Behera P, et al. Mitochondrial bioenergetics is not impaired in nonobese subjects with type 2 diabetes mellitus. Metab Clin Exp. 2011;60(12):1702-1710. https://doi.org/ 10.1016/j.metabol.2011.04.015

75. Fischer B, Schottl T, Schempp C, et al. Inverse relationship between body mass index and mitochondrial oxidative phosphorylation capacity in human subcutaneous adipocytes. Am J Physiol Endocrinol Metab. 2015;309(4):E380-E387. https://doi.org/10.1152/ajpendo.00524. 2014

76. Ejarque $M$, Ceperuelo-Mallafré $V$, Serena $C$, et al. Adipose tissue mitochondrial dysfunction in human obesity is linked to a specific DNA methylation signature in adipose-derived stem cells. Int $J$ Obes (Lond). 2019;43(6):1256-1268. https://doi.org/10.1038/s41366018-0219-6

77. Lindinger PW, Christe M, Eberle AN, et al. Important mitochondrial proteins in human omental adipose tissue show reduced expression in obesity. J Proteomics. 2015;124:79-87. https://doi.org/10.1016/j. jprot.2015.03.037

78. Xie X, Yi Z, Sinha S, et al. Proteomics analyses of subcutaneous adipocytes reveal novel abnormalities in human insulin resistance. Obesity (Silver Spring). 2016;24(7):1506-1514. https://doi.org/10.1002/ oby. 21528

79. Gómez-Serrano M, Camafeita E, García-Santos E, et al. Proteomewide alterations on adipose tissue from obese patients as age-, diabetes- and gender-specific hallmarks. Sci Rep. 2016;6:25756. https://doi.org/10.1038/srep25756

80. Yang H, Wu JW, Wang SP, et al. Adipose-Specific Deficiency of Fumarate Hydratase in Mice Protects Against Obesity, Hepatic Steatosis, and Insulin Resistance. Diabetes. 2016;65(11):3396-3409. https://doi.org/10.2337/db16-0136

81. Vernochet C, Damilano F, Mourier A, et al. Adipose tissue mitochondrial dysfunction triggers a lipodystrophic syndrome with insulin resistance, hepatosteatosis, and cardiovascular complications. FASEB J. 2014;28(10):4408-4419. https://doi.org/10.1096/fj.14-253971 
82. Yeh LA, Lee KH, Kim KH. Regulation of rat liver acetyl-CoA carboxylase. Regulation of phosphorylation and inactivation of acetyl-CoA carboxylase by the adenylate energy charge. J Biol Chem. 1980;255 (6):2308-2314. http://ovidsp.ovid.com/ovidweb.cgi?T=JS\&CSC= $Y \& N E W S=N \& P A G E=$ fulltext\&D=med $2 \& A N=6102090$

83. Lan F, Cacicedo JM, Ruderman N, Ido Y. SIRT1 Modulation of the Acetylation Status, Cytosolic Localization, and Activity of LKB1. J Biol Chem. 2008;283(41):27628-27635. https://doi.org/10.1074/jbc. M805711200

84. Auguet T, Guiu-Jurado E, Berlanga A, et al. Downregulation of lipogenesis and fatty acid oxidation in the subcutaneous adipose tissue of morbidly obese women. Obesity. 2014;22(9):2032-2038. https:// doi.org/10.1002/oby.20809

85. Ratner C, Madsen AN, Kristensen LV, et al. Impaired oxidative capacity due to decreased CPT1b levels as a contributing factor to fat accumulation in obesity. Am J Physiol Integr Comp Physiol. 2015;308(11): R973-R982. https://doi.org/10.1152/ajpregu.00219.2014

86. Gao X, Li K, Hui X, et al. Carnitine palmitoyltransferase 1A prevents fatty acid-induced adipocyte dysfunction through suppression of cJun N-terminal kinase. Biochem J. 2011;435(3):723-732. https://doi. org/10.1042/BJ20101680

87. Warfel JD, Vandanmagsar B, Dubuisson OS, et al. Obesity, Diabetes and Energy Homeostasis: Examination of carnitine palmitoyltransferase 1 abundance in white adipose tissue: implications in obesity research. Am J Physiol Regul Integr Comp Physiol. 2017;312(5):R816-R820. https://doi.org/10.1152/AJPREGU.00520. 2016

88. Lee J, Ellis JM, Wolfgang MJ. Adipose fatty acid oxidation is required for thermogenesis and potentiates oxidative stress induced inflammation. Cell Rep. 2014;10(2):266-279. https://doi.org/10.1016/j. celrep.2014.12.023

89. Herman MA, She P, Peroni OD, Lynch CJ, Kahn BB. Adipose tissue branched chain amino acid (BCAA) metabolism modulates circulating BCAA levels. J Biol Chem. 2010;285(15):11348-11356. https://doi. org/10.1074/jbc.M109.075184

90. Lynch CJ, Adams SH. Branched-chain amino acids in metabolic signalling and insulin resistance. Nat Rev Endocrinol. 2014;10(12):723-736. https://doi.org/10.1038/nrendo.2014.171

91. She P, Van Horn C, Reid T, Hutson SM, Cooney RN, Lynch CJ. Obesity-related elevations in plasma leucine are associated with alterations in enzymes involved in branched-chain amino acid metabolism. Am J Physiol Endocrinol Metab. 2007;293(6):E1552-E1563. http://ovidsp.ovid.com/ovidweb.cgi?T=JS\&CSC=Y\&NEWS= $N \& P A G E=$ fulltext\&D=med5\&AN=17925455

92. Felig P, Marliss E, Cahill GFJ. Plasma amino acid levels and insulin secretion in obesity. N Engl J Med. 1969;281(15):811-816. http:// ovidsp.ovid.com/ovidweb.cgi?T=JS\&CSC=Y\&NEWS=N\&PAGE= fulltext\&D=med1\&AN=5809519

93. Mardinoglu A, Kampf C, Asplund A, et al. Defining the Human Adipose Tissue Proteome To Reveal Metabolic Alterations in Obesity. J Proteome Res. 2014;13(11):5106-5119. https://doi.org/10.1021/ pr500586e

94. Naukkarinen J, Heinonen S, Hakkarainen A, et al. Characterising metabolically healthy obesity in weight-discordant monozygotic twins. Diabetologia. 2014;57(1):167-176. https://doi.org/10.1007/s00125013-3066-y

95. Muniandy M, Heinonen S, Yki-Järvinen $\mathrm{H}$, et al. Gene expression profile of subcutaneous adipose tissue in BMI-discordant monozygotic twin pairs unravels molecular and clinical changes associated with sub-types of obesity. Int J Obes (Lond). 2017;41(8):1176-1184. https://doi.org/10.1038/ijo.2017.95
96. Rämö JT, Kaye SM, Jukarainen S, et al. Liver Fat and Insulin Sensitivity Define Metabolite Profiles During a Glucose Tolerance Test in Young Adult Twins. J Clin Endocrinol Metab. 2016;102(1):220-231. https:// doi.org/10.1210/jc.2015-3512

97. Wang TJ, Larson MG, Vasan RS, et al. Metabolite profiles and the risk of developing diabetes. Nat Med. 2011;17(4):448-453. https://doi. org/10.1038/nm.2307

98. Lu J, Xie G, Jia W, Jia W. Insulin resistance and the metabolism of branched-chain amino acids. Front Med. 2013;7(1):53-59. https:// doi.org/10.1007/s11684-013-0255-5

99. Batch BC, Shah SH, Newgard CB, et al. Branched chain amino acids are novel biomarkers for discrimination of metabolic wellness. Metab Clin Exp. 2013;62(7):961-969. https://doi.org/10.1016/j. metabol.2013.01.007

100. Huang Y, Zhou M, Sun H, Wang Y. Branched-chain amino acid metabolism in heart disease: an epiphenomenon or a real culprit? Cardiovasc Res. 2011;90(2):220-223. https://doi.org/10.1093/cvr/ cvr070

101. Zhang Y, Guo K, LeBlanc RE, Loh D, Schwartz GJ, Yu Y-H. Increasing dietary leucine intake reduces diet-induced obesity and improves glucose and cholesterol metabolism in mice via multimechanisms. Diabetes. 2007;56(6):1647-1654. http://ovidsp.ovid.com/ovidweb. cgi? $T=J S \& C S C=Y \& N E W S=N \& P A G E=$ fulltext $\& D=$ med5\&AN $=$ 17360978

102. She P, Reid TM, Bronson SK, et al. Disruption of BCATm in mice leads to increased energy expenditure associated with the activation of a futile protein turnover cycle. Cell Metab. 2007;6(3):181-194. http:// ovidsp.ovid.com/ovidweb.cgi?T=JS\&CSC=Y\&NEWS=N\&PAGE= fulltext\&D=med5\&AN=17767905

103. Cummins TD, Holden CR, Sansbury BE, et al. Metabolic remodeling of white adipose tissue in obesity. Am J Physiol Endocrinol Metab. 2014;307(3):E262-E277. https://doi.org/10.1152/ajpendo.00271. 2013

104. Keuper M, Berti L, Raedle B, et al. Preadipocytes of obese humans display gender-specific bioenergetic responses to glucose and insulin. Mol Metab. 2018;20:28-37. https://doi.org/10.1016/j.molmet.2018. 11.006

105. Brahimi-Horn MC, Pouyssegur J. Oxygen, a source of life and stress. FEBS Lett. 2007;581(19):3582-3591. http://ovidsp.ovid.com/ ovidweb.cgi? $T=J S \& C S C=Y \& N E W S=N \& P A G E=$ fulltext $\& D=$ med5\&AN $=17586500$

106. O'Rourke RW, White AE, Metcalf MD, et al. Hypoxia-induced inflammatory cytokine secretion in human adipose tissue stromovascular cells. Diabetologia. 2011;54(6):1480-1490. https://doi.org/10.1007/ s00125-011-2103-y

107. Rausch ME, Weisberg S, Vardhana P, Tortoriello DV. Obesity in $\mathrm{C} 57 \mathrm{BL} / 6 \mathrm{~J}$ mice is characterized by adipose tissue hypoxia and cytotoxic T-cell infiltration. Int J Obes (Lond). 2008;32(3):451-463. http://ovidsp.ovid.com/ovidweb.cgi?T=JS\&CSC=Y\&NEWS= $N \& P A G E=$ fulltext\&D=med5\&AN=17895881

108. Ye J, Gao Z, Yin J, He Q. Hypoxia is a potential risk factor for chronic inflammation and adiponectin reduction in adipose tissue of ob/ob and dietary obese mice. Am J Physiol Endocrinol Metab. 2007;293(4): E1118-E1128. http://ovidsp.ovid.com/ovidweb.cgi?T=JS\&CSC= $Y \& N E W S=N \& P A G E=$ fulltext\&D=med5\&AN $=17666485$

109. Seo JB, Riopel M, Cabrales $P$, et al. Knockdown of ANT2 reduces adipocyte hypoxia and improves insulin resistance in obesity. Nat Metab. 2019;1(1):86-97. https://doi.org/10.1038/s42255-018-0003-x

110. Pasarica M, Xie H, Hymel D, et al. Lower total adipocyte number but no evidence for small adipocyte depletion in patients with type 2 diabetes. Diabetes Care. 2009;32(5):900-902. http://ovidsp.ovid.com/ 
ovidweb.cgi? $T=J S \& C S C=Y \& N E W S=N \& P A G E=$ fulltext $\& D=$ medI\&AN=19228873

111. Goossens GH, Bizzarri A, Venteclef N, et al. Increased adipose tissue oxygen tension in obese compared with lean men is accompanied by insulin resistance, impaired adipose tissue capillarization, and inflammation. Circulation. 2011;124(1):67-76. https://doi.org/10.1161/ CIRCULATIONAHA.111.027813

112. Vink RG, Roumans NJ, Čajlaković $M$, et al. Diet-induced weight loss decreases adipose tissue oxygen tension with parallel changes in adipose tissue phenotype and insulin sensitivity in overweight humans. Int J Obes (Lond). 2017;41(5):722-728. https://doi.org/10.1038/ ijo.2017.38

113. Hodson L, Humphreys SM, Karpe F, Frayn KN. Metabolic signatures of human adipose tissue hypoxia in obesity. Diabetes. 2013;62 (5):1417-1425.

114. Goossens GH, Blaak EE. Adipose tissue dysfunction and impaired metabolic health in human obesity: a matter of oxygen? Front Endocrinol (Lausanne). 2015;6:55. https://doi.org/10.3389/ fendo.2015.00055

115. Cedikova $M$, Kripnerová $M$, Dvorakova J, et al. Mitochondria in White, Brown, and Beige Adipocytes. Stem Cells Int. 2016;2016:6067349. https://doi.org/10.1155/2016/6067349

116. Rognstad R, Katz J. The effect of 2,4-dinitrophenol on adipose-tissue metabolism. Biochem J. 1969;111(4):431-444. http://ovidsp.ovid. com/ovidweb.cgi?T=JS\&CSC=Y\&NEWS=N\&PAGE=fulltext\&D= med1\&AN=4388239

117. Kopecky J, Rossmeisl M, Flachs P, Bardova K, Brauner P. Mitochondrial uncoupling and lipid metabolism in adipocytes. Biochem Soc Trans. 2001;29(Pt 6):791-797. http://ovidsp.ovid.com/ovidweb.cgi? $T=J S \& C S C=Y \& N E W S=N \& P A G E=$ fulltext $\& D=$ med $4 \& A N=11709076$

118. Sztalryd C, Kraemer FB. Regulation of hormone-sensitive lipase in streptozotocin-induced diabetic rats. Metab Clin Exp. 1995;44 (11):1391-1396. http://ovidsp.ovid.com/ovidweb.cgi?T=JS\&CSC= $Y \& N E W S=N \& P A G E=$ fulltext $\& D=$ med $3 \& A N=7476323$

119. Zimmermann R, Strauss JG, Haemmerle G, et al. Fat mobilization in adipose tissue is promoted by adipose triglyceride lipase. Science (80-). 2004;306(5700):1383-1386. http://ovidsp.ovid.com/ovidweb. cgi? $T=J S \& C S C=Y \& N E W S=N \& P A G E=$ fulltext $\& D=$ med $5 \& A N=$ 15550674

120. Fassina G, Dorigo P, Gaion RM. Equilibrium between metabolic pathways producing energy: a key factor in regulating lipolysis. Pharmacol Res Commun. 1974;6(1):1-21. http://ovidsp.ovid.com/ovidweb.cgi?T= $J S \& C S C=Y \& N E W S=N \& P A G E=$ fulltext $\& D=$ med $1 \& A N=4372642$

121. Lafontan M, Moro C, Berlan M, Crampes F, Sengenes C, Galitzky J. Control of lipolysis by natriuretic peptides and cyclic GMP. Trends Endocrinol Metab. 2008;19(4):130-137. https://doi.org/10.1016/j. tem.2007.11.006

122. Karastergiou K, Fried SK. Multiple adipose depots increase cardiovascular risk via local and systemic effects. Curr Atheroscler Rep. 2013;15 (10):361. https://doi.org/10.1007/s11883-013-0361-5

123. Girousse A, Langin D. Adipocyte lipases and lipid droplet-associated proteins: insight from transgenic mouse models. Int J Obes (Lond). 2012;36(4):581-594. https://doi.org/10.1038/ijo.2011.113

124. Jocken JWE, Langin D, Smit E, et al. Adipose triglyceride lipase and hormone-sensitive lipase protein expression is decreased in the obese insulin-resistant state. J Clin Endocrinol Metab. 2007;92 (6):2292-2299. https://doi.org/10.1210/jc.2006-1318

125. Jocken JWE, Goossens GH, Popeijus H, Essers Y, Hoebers N, Blaak EE. Contribution of lipase deficiency to mitochondrial dysfunction and insulin resistance in hMADS adipocytes. Int J Obes (Lond). 2016;40(3):507-513. https://doi.org/10.1038/ijo.2015.211
126. Arner P, Andersson DP, Bäckdahl J, Dahlman I, Rydén M. Weight Gain and Impaired Glucose Metabolism in Women Are Predicted by Inefficient Subcutaneous Fat Cell Lipolysis. Cell Metab. 2018;28 (1):45-54.e3. https://doi.org/10.1016/j.cmet.2018.05.004

127. Rasouli N, Kern PA. Adipocytokines and the metabolic complications of obesity. J Clin Endocrinol Metab. 2008;93(11 Suppl 1):S64-S73. https://doi.org/10.1210/jc.2008-1613

128. Ahima RS. Adipose tissue as an endocrine organ. Obesity. 2006;14 (Suppl 5):242S-249S. http://ovidsp.ovid.com/ovidweb.cgi?T= $J S \& C S C=Y \& N E W S=N \& P A G E=$ fulltext $\& D=$ med5\&AN $=17021375$

129. Mohamed-Ali V, Pinkney JH, Coppack SW. Adipose tissue as an endocrine and paracrine organ. Int J Obes Relat Metab Disord J Int Assoc Study Obes. 1998;22(12):1145-1158. http://ovidsp.ovid.com/ ovidweb.cgi? $T=J S \& C S C=Y \& N E W S=N \& P A G E=$ fulltext $\& D=$ med4\&AN=9877249

130. Charo IF, Ransohoff RM. The many roles of chemokines and chemokine receptors in inflammation. N Engl J Med. 2006;354(6):610-621. http://ovidsp.ovid.com/ovidweb.cgi?T=JS\&CSC=Y\&NEWS= $N \& P A G E=$ fulltext\&D=med5\&AN $=16467548$

131. Klok MD, Jakobsdottir S, Drent ML. The role of leptin and ghrelin in the regulation of food intake and body weight in humans: a review. Obes Rev. 2007;8(1):21-34. https://doi.org/10.1111/j.1467789X.2006.00270.x

132. Takekoshi K, Motooka M, Isobe K, et al. Leptin directly stimulates catecholamine secretion and synthesis in cultured porcine adrenal medullary chromaffin cells. Biochem Biophys Res Commun. 1999;261 (2):426-431. http://ovidsp.ovid.com/ovidweb.cgi?T=JS\&CSC= $Y \& N E W S=N \& P A G E=$ fulltext\&D=med4\&AN=10425201

133. Gainsford T, Willson TA, Metcalf D, et al. Leptin can induce proliferation, differentiation, and functional activation of hemopoietic cells. Proc Natl Acad Sci U S A. 1996;93(25):14564-14568. http://ovidsp. ovid.com/ovidweb.cgi?T=JS\&CSC $=Y \& N E W S=N \& P A G E=$ fulltext\&D= med4\&AN=8962092

134. Heilbronn LK, Smith SR, Ravussin E. The insulin-sensitizing role of the fat derived hormone adiponectin. Curr Pharm Des. 2003;9 (17):1411-1418. http://ovidsp.ovid.com/ovidweb.cgi?T=JS\&CSC= $Y \& N E W S=N \& P A G E=$ fulltext $\& D=$ med $4 \& A N=12769732$

135. Wedellova Z, Dietrich J, Siklova-Vitkova M, et al. Adiponectin inhibits spontaneous and catecholamine-induced lipolysis in human adipocytes of non-obese subjects through AMPK-dependent mechanisms. Physiol Res. 2011;60(1):139-148. http://ovidsp.ovid. com/ovidweb.cgi?T=JS\&CSC=Y\&NEWS=N\&PAGE=fulltext\&D= med5\&AN $=20945960$

136. Lazra Y, Falach A, Frenkel L, Rozenberg K, Sampson S, Rosenzweig T. Autocrine/paracrine function of globular adiponectin: inhibition of lipid metabolism and inflammatory response in 3T3-L1 adipocytes. J Cell Biochem. 2015;116(5):754-766. https://doi.org/10.1002/ jcb.25031

137. Koh EH, Park J-Y, Park H-S, et al. Essential role of mitochondrial function in adiponectin synthesis in adipocytes. Diabetes. 2007;56 (12):2973-2981. http://ovidsp.ovid.com/ovidweb.cgi?T=JS\&CSC= $Y \& N E W S=N \& P A G E=$ fulltext\&D=med5\&AN=17827403

138. Wang $\mathrm{CH}$, Wang $\mathrm{CC}$, Huang $\mathrm{HC}$, Wei YH. Mitochondrial dysfunction leads to impairment of insulin sensitivity and adiponectin secretion in adipocytes. FEBS J. 2013;280(4):1039-1050. https://doi.org/ 10.1111/febs.12096

139. Koh EH, Kim A-R, Kim H, et al. 11ß-HSD1 reduces metabolic efficacy and adiponectin synthesis in hypertrophic adipocytes. J Endocrinol. 2015;225(3):147-158. https://doi.org/10.1530/JOE-15-0117

140. Liu Z, Gan L, WuT, et al. Adiponectin reduces ER stress-induced apoptosis through PPARa transcriptional regulation of ATF2 in mouse 
adipose. Cell Death Dis. 2016;7(11):e2487-e2487. https://doi.org/ 10.1038/cddis.2016.388

141. Cawthorn WP, Scheller EL, MacDougald OA. Adipose tissue stem cells meet preadipocyte commitment: going back to the future. J Lipid Res. 2012;53(2):227-246. https://doi.org/10.1194/jlr.R021089

142. Rodeheffer MS, Birsoy K, Friedman JM. Identification of white adipocyte progenitor cells in vivo. Cell. 2008;135(2):240-249. https://doi. org/10.1016/j.cell.2008.09.036

143. Tang W, Zeve D, Suh JM, et al. White fat progenitor cells reside in the adipose vasculature. Science (80-). 2008;322(5901):583-586. https:// doi.org/10.1126/science.1156232

144. Rosen ED, Spiegelman BM. PPARgamma: a nuclear regulator of metabolism, differentiation, and cell growth. J Biol Chem. 2001;276 (41):37731-37734. http://ovidsp.ovid.com/ovidweb.cgi?T=JS\&CSC= $Y \& N E W S=N \& P A G E=$ fulltext\&D=med4\&AN $=11459852$

145. Vankoningsloo S, De Pauw A, Houbion A, et al. CREB activation induced by mitochondrial dysfunction triggers triglyceride accumulation in 3T3-L1 preadipocytes. J Cell Sci. 2006;119(Pt 7):1266-1282. http://ovidsp.ovid.com/ovidweb.cgi?T=JS\&CSC $=$ Y\&NEWS= N\&PAGE=fulltext\&D=med5\&AN=16537646, https://doi.org/ $10.1242 /$ jcs. 02848

146. Ijichi N, Ikeda K, Horie-Inoue K, Yagi K, Okazaki Y, Inoue S. Estrogenrelated receptor alpha modulates the expression of adipogenesisrelated genes during adipocyte differentiation. Biochem Biophys Res Commun. 2007;358(3):813-818. http://ovidsp.ovid.com/ovidweb. cgi? $T=J S \& C S C=Y \& N E W S=N \& P A G E=$ fulltext $\& D=$ med5\&AN $=$ 17512501

147. Spiegelman BM, Puigserver $P, W u Z$. Regulation of adipogenesis and energy balance by PPARgamma and PGC-1. Int J Obes Relat Metab Disord J Int Assoc Study Obes. 2000;24(Suppl 4):S8-S10. http:// ovidsp.ovid.com/ovidweb.cgi?T=JS\&CSC=Y\&NEWS=N\&PAGE $=$ fulltext\&D=med $4 \& A N=11126248$

148. Rosen ED, Spiegelman BM. Molecular Regulation of Adipogenesis. Annu Rev Cell Dev Biol. 2002;16(1):145-171. https://doi.org/ 10.1146/annurev.cellbio.16.1.145

149. Wilson-Fritch L, Burkart A, Bell G, et al. Mitochondrial biogenesis and remodeling during adipogenesis and in response to the insulin sensitizer rosiglitazone. Mol Cell Biol. 2003;23(3):1085-1094. http:// ovidsp.ovid.com/ovidweb.cgi?T=JS\&CSC=Y\&NEWS=N\&PAGE $=$ fulltext\&D=med $4 \& A N=12529412$

150. Kitsy A, Carney S, Vivar JC, et al. Effects of leucine supplementation and serum withdrawal on branched-chain amino acid pathway gene and protein expression in mouse adipocytes. PLOS ONE [Electronic Resour]. 2014;9(7):e102615. https://doi.org/10.1371/journal. pone. 0102615

151. Green CR, Wallace M, Divakaruni AS, et al. Branched-chain amino acid catabolism fuels adipocyte differentiation and lipogenesis. Nat Chem Biol. 2016;12(1):15-21. https://doi.org/10.1038/nchembio. 1961

152. Blanchard P-G, Festuccia WT, Houde VP, et al. Major involvement of mTOR in the PPAR $\gamma$-induced stimulation of adipose tissue lipid uptake and fat accretion. J Lipid Res. 2012;53(6):1117-1125. https://doi.org/10.1194/jlr.M021485

153. Carriere A, Fernandez Y, Rigoulet M, Penicaud L, Casteilla L. Inhibition of preadipocyte proliferation by mitochondrial reactive oxygen species. FEBS Lett. 2003;550(1-3):163-167. http://ovidsp.ovid.com/ ovidweb.cgi? $T=J S \& C S C=Y \& N E W S=N \& P A G E=$ fulltext\&D= med4\&AN=12935904

154. Carriere A, Carmona M-C, Fernandez Y, et al. Mitochondrial reactive oxygen species control the transcription factor CHOP-10/GADD153 and adipocyte differentiation: a mechanism for hypoxia-dependent effect. J Biol Chem. 2004;279(39):40462-40469. http://ovidsp.ovid. com/ovidweb.cgi?T=JS\&CSC=Y\&NEWS=N\&PAGE=fulltext\&D= med5\&AN=15265861

155. Lu R, Ji H, Chang Z, Su S, Yang G. Mitochondrial development and the influence of its dysfunction during rat adipocyte differentiation. Mol Biol Rep. 2010;37(5):2173-2182. https://doi.org/10.1007/s11033009-9695-z

156. Kras KM, Hausman DB, Hausman GJ, Martin RJ. Adipocyte development is dependent upon stem cell recruitment and proliferation of preadipocytes. Obes Res. 1999;7(5):491-497. http://ovidsp.ovid. com/ovidweb.cgi?T=JS\&CSC=Y\&NEWS=N\&PAGE=fulltext\&D= med4\&AN=10509607

157. Salans LB, Knittle JL, Hirsch J. The role of adipose cell size and adipose tissue insulin sensitivity in the carbohydrate intolerance of human obesity. J Clin Invest. 1968;47(1):153-165. http://ovidsp. ovid.com/ovidweb.cgi?T=JS\&CSC $=Y \& N E W S=N \& P A G E=$ fulltext $\& D=$ prem\&AN=16695937

158. Hoffstedt J, Arner E, Wahrenberg H, et al. Regional impact of adipose tissue morphology on the metabolic profile in morbid obesity. Diabetologia. 2010;53(12):2496-2503. http://ovidsp.ovid.com/ ovidweb.cgi?T=JS\&CSC $=Y \& N E W S=N \& P A G E=$ fulltext\&D= medI\&AN=20830466

159. Andersson DP, Hogling DE, Thorell A, et al. Changes in subcutaneous fat cell volume and insulin sensitivity after weight loss. Diabetes Care. 2014;37(7):1831-1836. https://doi.org/10.2337/dc13-2395

160. Larson-Meyer DE, Heilbronn LK, Redman LM, et al. Effect of calorie restriction with or without exercise on insulin sensitivity, beta-cell function, fat cell size, and ectopic lipid in overweight subjects. Diabetes Care. 2006;29(6):1337-1344. http://ovidsp.ovid.com/ovidweb. cgi? $T=J S \& C S C=Y \& N E W S=N \& P A G E=$ fulltext $\& D=$ med5\&AN $=$ 16732018

161. Gao H, Mejhert N, Fretz JA, et al. Early B cell factor 1 regulates adipocyte morphology and lipolysis in white adipose tissue. Cell Metab. 2014;19(6):981-992. https://doi.org/10.1016/j.cmet.2014. 03.032

162. Jernas M, Palming J, Sjoholm K, et al. Separation of human adipocytes by size: hypertrophic fat cells display distinct gene expression. FASEB J. 2006;20(9):1540-1542. http://ovidsp.ovid.com/ovidweb.cgi?T= $J S \& C S C=Y \& N E W S=N \& P A G E=$ fulltext\&D=medc\&AN $=16754744$

163. Skurk T, Alberti-Huber C, Herder C, Hauner H. Relationship between adipocyte size and adipokine expression and secretion. J Clin Endocrinol Metab. 2007;92(3):1023-1033. http://ovidsp.ovid.com/ ovidweb.cgi? $T=J S \& C S C=Y \& N E W S=N \& P A G E=$ fulltext $\& D=$ med5\&AN=17164304

164. Weisberg SP, McCann D, Desai M, Rosenbaum M, Leibel RL, Ferrante AWJ. Obesity is associated with macrophage accumulation in adipose tissue. J Clin Invest. 2003;112(12):1796-1808. http://ovidsp.ovid. com/ovidweb.cgi?T=JS\&CSC=Y\&NEWS=N\&PAGE=fulltext\&D= med4\&AN=14679176

165. Lu Q, Li M, Zou Y, Cao T. Induction of adipocyte hyperplasia in subcutaneous fat depot alleviated type 2 diabetes symptoms in obese mice. Obesity. 2014;22(7):1623-1631. https://doi.org/10.1002/oby.20705

166. Spalding KL, Arner E, Westermark PO, et al. Dynamics of fat cell turnover in humans. Nature. 2008;453(7196):783-787. https://doi.org/ 10.1038/nature06902

167. Heinonen S, Saarinen L, Naukkarinen J, et al. Adipocyte Morphology and Implications for Metabolic Derangements in Acquired Obesity. Int J Obes (Lond). 2014;38(11):1423-1431.

168. Salans LB, Horton ES, Sims EA. Experimental obesity in man: cellular character of the adipose tissue. J Clin Invest. 1971;50(5):1005-1011. 
169. Permana PA, Nair S, Lee YH, Luczy-Bachman G, De Courten BV, Tataranni PA. Subcutaneous abdominal preadipocyte differentiation in vitro inversely correlates with central obesity. Am J Physiol Endocrinol Metab. 2004;286(6):E958-E962. http://ovidsp.ovid.com/ ovidweb.cgi? $T=J S \& C S C=Y \& N E W S=N \& P A G E=$ fulltext $\& D=$ med4\&AN=14970008

170. van Tienen FH, van der Kallen CJ, Lindsey PJ, Wanders RJ, van Greevenbroek MM, Smeets HJ. Preadipocytes of type 2 diabetes subjects display an intrinsic gene expression profile of decreased differentiation capacity. Int J Obes (Lond). 2011;35(9):1154-1164. https://doi.org/10.1038/ijo.2010.275

171. Lagathu C, Christodoulides C, Virtue S, et al. Dact1, a nutritionally regulated preadipocyte gene, controls adipogenesis by coordinating the Wnt/beta-catenin signaling network. Diabetes. 2009;58 (3):609-619. https://doi.org/10.2337/db08-1180

172. Pérez LM, Bernal A, de Lucas B, et al. Altered metabolic and stemness capacity of adipose tissue-derived stem cells from obese mouse and human. Engler AJ, ed. PLoS ONE. 2015;10(4):e0123397. https://doi. org/10.1371/journal.pone.0123397

173. Kloting N, Fasshauer M, Dietrich A, et al. Insulin-sensitive obesity. Am J Physiol Endocrinol Metab. 2010;299(3):E506-E515. https://doi.org/ 10.1152/ajpendo.00586.2009

174. O'Connell J, Lynch L, Cawood TJ, et al. The relationship of omental and subcutaneous adipocyte size to metabolic disease in severe obesity. PLoS ONE [Electronic Resour]. 2010;5(4):e9997. https://doi.org/ 10.1371/journal.pone.0009997

175. Pataky Z, Bobbioni-Harsch E, Golay A. Open questions about metabolically normal obesity. Int J Obes (Lond). 2010;34(Suppl 2): S18-S23. https://doi.org/10.1038/ijo.2010.235

176. McLaughlin T, Sherman A, Tsao P, et al. Enhanced proportion of small adipose cells in insulin-resistant vs insulin-sensitive obese individuals implicates impaired adipogenesis. Diabetologia. 2007;50 (8):1707-1715. http://ovidsp.ovid.com/ovidweb.cgi?T=JS\&CSC= $Y \& N E W S=N \& P A G E=$ fulltext $\& D=$ med4\&AN $=17549449$

177. Rutkowski JM, Stern JH, Scherer PE. The cell biology of fat expansion. J Cell Biol. 2015;208(5):501-512. https://doi.org/10.1083/ jcb.201409063

178. Gustafson B, Hedjazifar S, Gogg S, Hammarstedt A, Smith U. Insulin resistance and impaired adipogenesis. Trends Endocrinol Metab. 2015;26(4):193-200. https://doi.org/10.1016/j.tem.2015.01.006

179. Arner E, Westermark PO, Spalding KL, et al. Adipocyte turnover: relevance to human adipose tissue morphology. Diabetes. 2010;59 (1):105-109. https://doi.org/10.2337/db09-0942

180. Eriksson-Hogling D, Andersson DP, Bäckdahl J, et al. Adipose tissue morphology predicts improved insulin sensitivity following moderate or pronounced weight loss. Int J Obes (Lond). 2015;39(6):893-898.

181. Deveaud C, Beauvoit B, Salin B, Schaeffer J, Rigoulet M. Regional differences in oxidative capacity of rat white adipose tissue are linked to the mitochondrial content of mature adipocytes. Mol Cell Biochem. 2004;267(1-2):157-166. https://www.ncbi.nlm.nih.gov/pubmed/ 15663197

182. Kraunsoe R, Boushel R, Hansen CN, et al. Mitochondrial respiration in subcutaneous and visceral adipose tissue from patients with morbid obesity. J Physiol. 2010;588(Pt 12):2023-2032. https://doi.org/ 10.1113/jphysiol.2009.184754

183. Turner N, Heilbronn LK. Is mitochondrial dysfunction a cause of insulin resistance? Trends Endocrinol Metab. 2008;19(9):324-330. https:// doi.org/10.1016/j.tem.2008.08.001

184. Xu XJ, Gauthier M-S, Hess DT, et al. Insulin sensitive and resistant obesity in humans: AMPK activity, oxidative stress, and depot- specific changes in gene expression in adipose tissue. J Lipid Res. 2012;53(4):792-801. https://doi.org/10.1194/jlr.P022905

185. Gao CL, Zhu C, Zhao YP, et al. Mitochondrial dysfunction is induced by high levels of glucose and free fatty acids in 3T3-L1 adipocytes. Mol Cell Endocrinol. 2010;320(1-2):25-33. https://doi.org/10.1016/j. mce.2010.01.039

186. Sutherland LN, Capozzi LC, Turchinsky NJ, Bell RC, Wright DC. Time course of high-fat diet-induced reductions in adipose tissue mitochondrial proteins: potential mechanisms and the relationship to glucose intolerance. Am J Physiol Endocrinol Metab. 2008;295(5): E1076-E1083. https://doi.org/10.1152/ajpendo.90408.2008

187. Paglialunga S, Ludzki A, Root-McCaig J, Holloway GP. In adipose tissue, increased mitochondrial emission of reactive oxygen species is important for short-term high-fat diet-induced insulin resistance in mice. Diabetologia. 2015;58(5):1071-1080. https://doi.org/10.1007/ s00125-015-3531-x

188. Wang P-W, Kuo H-M, Huang H-T, et al. Biphasic response of mitochondrial biogenesis to oxidative stress in visceral fat of dietinduced obesity mice. Antioxid Redox Signal. 2014;20 (16):2572-2588. https://doi.org/10.1089/ars.2013.5334

189. Anderson EJ, Lustig ME, Boyle KE, et al. Mitochondrial $\mathrm{H} 2 \mathrm{O} 2$ emission and cellular redox state link excess fat intake to insulin resistance in both rodents and humans. J Clin Invest. 2009;119 (3):573-581. https://doi.org/10.1172/JCI37048

190. Hoehn KL, Salmon AB, Hohnen-Behrens C, et al. Insulin resistance is a cellular antioxidant defense mechanism. Proc Natl Acad Sci U S A. 2009;106(42):17787-17792. pnas.0902380106

https://doi.org/10.1073/

191. Furukawa S, Fujita T, Shimabukuro M, et al. Increased oxidative stress in obesity and its impact on metabolic syndrome. J Clin Invest. 2004;114(12):1752-1761. https://doi.org/10.1172/JCI21625

192. Fazakerley DJ, Minard AY, Krycer JR, et al. Mitochondrial oxidative stress causes insulin resistance without disrupting oxidative phosphorylation. J Biol Chem. 2018;293(19):7315-7328. https://doi.org/ 10.1074/jbc.RA117.001254

193. Shi X, Burkart A, Nicoloro SM, Czech MP, Straubhaar J, Corvera S. Paradoxical effect of mitochondrial respiratory chain impairment on insulin signaling and glucose transport in adipose cells. J Biol Chem. 2008;283(45):30658-30667. https://doi.org/10.1074/jbc. M800510200

194. Savage DB, Petersen KF, Shulman GI. Disordered lipid metabolism and the pathogenesis of insulin resistance. Physiol Rev. 2007;87 (2):507-520. https://doi.org/10.1152/physrev.00024.2006

195. Holland WL, Summers SA. Sphingolipids, insulin resistance, and metabolic disease: new insights from in vivo manipulation of sphingolipid metabolism. Endocr Rev. 2008;29(4):381-402.

196. García-Ruiz C, Colell A, Marí M, Morales A, Fernández-Checa JC. Direct effect of ceramide on the mitochondrial electron transport chain leads to generation of reactive oxygen species. Role of mitochondrial glutathione. J Biol Chem. 1997;272(17):11369-11377. http://www.ncbi.nlm.nih.gov/pubmed/9111045 Accessed September 11, 2018

197. Martin SD, Morrison S, Konstantopoulos N, McGee SL. Mitochondrial dysfunction has divergent, cell type-dependent effects on insulin action. Mol Metab. 2014;3(4):408-418. https://doi.org/10.1016/j. molmet.2014.02.001

198. Enguix N, Pardo R, Gonzalez A, et al. Mice lacking PGC-1beta in adipose tissues reveal a dissociation between mitochondrial dysfunction and insulin resistance. Mol Metab. 2013;2(3):215-226. https://doi. org/10.1016/j.molmet.2013.05.004 
199. Christe M, Hirzel E, Lindinger A, et al. Obesity affects mitochondrial citrate synthase in human omental adipose tissue. ISRN Obes. 2013;2013:826027. https://doi.org/10.1155/2013/826027

200. Heinonen S, Saarinen L, Naukkarinen J, et al. Adipocyte morphology and implications for metabolic derangements in acquired obesity. Int J Obes (Lond). 2014;38(11):1423-1431. https://doi.org/10.1038/ ijo.2014.31

201. Pietilainen KH, Naukkarinen J, Rissanen A, et al. Global transcript profiles of fat in monozygotic twins discordant for BMI: pathways behind acquired obesity. PLoS Med/Public Libr Sci. 2008;5(3):e51. https://doi. org/10.1371/journal.pmed.0050051

202. Bashan N, Kovsan J, Kachko I, Ovadia H, Rudich A. Positive and Negative Regulation of Insulin Signaling by Reactive Oxygen and Nitrogen Species. Physiol Rev. 2009;89(1):27-71. https://doi.org/ 10.1152/physrev.00014.2008

203. Han CY, Umemoto T, Omer M, et al. NADPH oxidase-derived reactive oxygen species increases expression of monocyte chemotactic factor genes in cultured adipocytes. J Biol Chem. 2012;287(13): 10379-10393. https://doi.org/10.1074/jbc.M111.304998

204. Koves TR, Ussher JR, Noland RC, et al. Mitochondrial overload and incomplete fatty acid oxidation contribute to skeletal muscle insulin resistance. Cell Metab. 2008;7(1):45-56. https://doi.org/10.1016/j. cmet.2007.10.013

205. Chattopadhyay M, Khemka VK, Chatterjee G, Ganguly A, Mukhopadhyay S, Chakrabarti S. Enhanced ROS production and oxidative damage in subcutaneous white adipose tissue mitochondria in obese and type 2 diabetes subjects. Mol Cell Biochem. 2015;399(12):95-103. https://doi.org/10.1007/s11010-014-2236-7

206. Cinti S, Mitchell G, Barbatelli G, et al. Adipocyte death defines macrophage localization and function in adipose tissue of obese mice and humans. J Lipid Res. 2005;46(11):2347-2355. http://ovidsp.ovid. com/ovidweb.cgi?T=JS\&CSC=Y\&NEWS=N\&PAGE $=$ fulltext\&D $=$ med5\&AN=16150820

207. Ruan H, Lodish HF. Regulation of insulin sensitivity by adipose tissuederived hormones and inflammatory cytokines. Curr Opin Lipidol. 2004;15(3):297-302. http://ovidsp.ovid.com/ovidweb.cgi?T= $J S \& C S C=Y \& N E W S=N \& P A G E=$ fulltext\&D=med5\&AN $=15166785$

208. Permana PA, Menge C, Reaven PD. Macrophage-secreted factors induce adipocyte inflammation and insulin resistance. Biochem Biophys Res Commun. 2006;341(2):507-514. http://ovidsp.ovid.com/ ovidweb.cgi? $T=J S \& C S C=Y \& N E W S=N \& P A G E=$ fulltext $\& D=$ med5\&AN=16427608

209. Suganami T, Nishida J, Ogawa Y. A paracrine loop between adipocytes and macrophages aggravates inflammatory changes: role of free fatty acids and tumor necrosis factor alpha. Arterioscler Thromb Vasc Biol. 2005;25(10):2062-2068. http://ovidsp.ovid.com/ovidweb. cgi $? \mathrm{~T}=\mathrm{JS} \& C S C=Y \& N E W S=N \& P A G E=$ fulltext $\& D=$ med $5 \& A N=$ 16123319

210. Bremer J, Bjerve KS, Borrebaek B, Christiansen R. The glycerophosphateacyltransferases and their function in the metabolism of fatty acids. Mol Cell Biochem. 1976;12(2):113-125. http:// ovidsp.ovid.com/ovidweb.cgi?T=JS\&CSC=Y\&NEWS=N\&PAGE $=$ fulltext\&D=med $1 \& A N=958214$

211. Pietilainen KH, Rog T, Seppanen-Laakso T, et al. Association of lipidome remodeling in the adipocyte membrane with acquired obesity in humans. PLoS Biol. 2011;9(6):e1000623. http://ovidsp.ovid. com/ovidweb.cgi?T=JS\&CSC $=Y \& N E W S=N \& P A G E=$ fulltext\&D= medl\&AN=21666801

212. Valerio A, Cardile A, Cozzi V, et al. TNF-alpha downregulates eNOS expression and mitochondrial biogenesis in fat and muscle of obese rodents. J Clin Invest. 2006;116(10):2791-2798. http://ovidsp.ovid.
com/ovidweb.cgi?T=JS\&CSC=Y\&NEWS=N\&PAGE=fulltext\&D= med5\&AN=16981010

213. Dahlman I, Forsgren M, Sjogren A, et al. Downregulation of electron transport chain genes in visceral adipose tissue in type 2 diabetes independent of obesity and possibly involving tumor necrosis factor-alpha. Diabetes. 2006;55(6):1792-1799. http://ovidsp.ovid. com/ovidweb.cgi?T=JS\&CSC=Y\&NEWS=N\&PAGE=fulltext\&D= med5\&AN=16731844

214. Bogacka I, Ukropcova B, McNeil M, Gimble JM, Smith SR. Structural and functional consequences of mitochondrial biogenesis in human adipocytes in vitro. J Clin Endocrinol Metab. 2005;90(12):6650-6656. http://ovidsp.ovid.com/ovidweb.cgi?T=JS\&CSC $=Y \& N E W S=$ $N \& P A G E=$ fulltext $\& D=$ med5\&AN $=16204368$

215. Action to Control Cardiovascular Risk in Diabetes Study Group, Gerstein HC, Miller ME, et al. Effects of Intensive Glucose Lowering in Type 2 Diabetes. N Engl J Med. 2008;358(24):2545-2559. https:// doi.org/10.1056/NEJMoa0802743

216. Nissen SE. Cardiovascular Effects of Diabetes Drugs: Emerging From the Dark Ages. Ann Intern Med. 2012;157(9):671-672. https://doi. org/10.7326/0003-4819-157-9-201211060-00016

217. Asemi Z, Samimi M, Tabassi Z, Shakeri H, Esmaillzadeh A. Vitamin D supplementation affects serum high-sensitivity C-reactive protein, insulin resistance, and biomarkers of oxidative stress in pregnant women. J Nutr. 2013;143(9):1432-1438. https://doi.org/10.3945/ jn.113.177550

218. Fang F, Kang Z, Wong C. Vitamin E tocotrienols improve insulin sensitivity through activating peroxisome proliferator-activated receptors. Mol Nutr Food Res. 2010;54(3):345-352. https://doi.org/ 10.1002/mnfr.200900119

219. Shen W, Liu K, Tian C, et al. R-alpha-lipoic acid and acetyl-L-carnitine complementarily promote mitochondrial biogenesis in murine 3T3-L1 adipocytes. Diabetologia. 2008;51(1):165-174. http://ovidsp.ovid. com/ovidweb.cgi?T=JS\&CSC $=Y \& N E W S=N \& P A G E=$ fulltext\&D= med5\&AN=18026715

220. Mingrone G. Carnitine in Type 2 Diabetes. Ann N Y Acad Sci. 2004;1033(1):99-107. https://doi.org/10.1196/annals.1320.009

221. Ros RD, Assaloni R, Ceriello A. Molecular targets of diabetic vascular complications and potential new drugs. Curr Drug Targets. 2005;6:503. https://doi.org/10.2174/1389450054021855

222. de Oliveira AM, Rondo PHC, Luzia LA, D'Abronzo FH, Illison VK. The effects of lipoic acid and alpha-tocopherol supplementation on the lipid profile and insulin sensitivity of patients with type 2 diabetes mellitus: a randomized, double-blind, placebo-controlled trial. Diabetes Res Clin Pract. 2011;92(2):253-260. https://doi.org/10.1016/j. diabres.2011.02.010

223. Czernichow S, Vergnaud A-C, Galan P, et al. Effects of long-term antioxidant supplementation and association of serum antioxidant concentrations with risk of metabolic syndrome in adults. Am J Clin Nutr. 2009;90(2):329-335. https://doi.org/10.3945/ajcn.2009.27635

224. Harper JA, Dickinson K, Brand MD. Mitochondrial uncoupling as a target for drug development for the treatment of obesity. Obes Rev. 2001;2(4):255-265. http://ovidsp.ovid.com/ovidweb.cgi?T= $J S \& C S C=Y \& N E W S=N \& P A G E=$ fulltext $\& D=$ med $4 \& A N=12119996$

225. Hsiao AL, Santucci KA, Seo-Mayer P, et al. Pediatric fatality following ingestion of dinitrophenol: postmortem identification of a "dietary supplement". Clin Toxicol Off J Am Acad Clin Toxicol Eur Assoc Poisons Centres Clin Toxicol. 2005;43(4):281-285. http://ovidsp.ovid.com/ ovidweb.cgi? $T=J S \& C S C=Y \& N E W S=N \& P A G E=$ fulltext $\& D=$ med5\&AN=16035205

226. Toledo FGS, Menshikova EV, Ritov VB, et al. Effects of Physical Activity and Weight Loss on Skeletal Muscle Mitochondria and 
Relationship With Glucose Control in Type 2 Diabetes. Diabetes. 2007;56(8):2142-2147. https://doi.org/10.2337/db07-0141

227. Friedlander AL, Casazza GA, Horning MA, Buddinger TF, Brooks GA. Effects of exercise intensity and training on lipid metabolism in young women. Am J Physiol Metab. 1998;275(5):E853-E863. https://doi. org/10.1152/ajpendo.1998.275.5.E853

228. Sun K, Asterholm IW, Kusminski CM, et al. Dichotomous effects of VEGF-A on adipose tissue dysfunction. Proc Natl Acad Sci. 2012;109(15):5874-5879. https://doi.org/10.1073/pnas.12004 47109

229. Kitada M, Kume S, Takeda-Watanabe A, Tsuda S, Kanasaki K, Koya D. Calorie restriction in overweight males ameliorates obesity-related metabolic alterations and cellular adaptations through anti-aging effects, possibly including AMPK and SIRT1 activation. Biochim Biophys Acta. 2013;1830(10):4820-4827. https://doi.org/10.1016/j. bbagen.2013.06.014

230. Schenk S, McCurdy CE, Philp A, et al. Sirt1 enhances skeletal muscle insulin sensitivity in mice during caloric restriction. J Clin Invest. 2011;121(11):4281-4288. https://doi.org/10.1172/JCI58554

231. Milne JC, Lambert PD, Schenk S, et al. Small molecule activators of SIRT1 as therapeutics for the treatment of type 2 diabetes. Nature. 2007;450(7170):712-716. http://ovidsp.ovid.com/ovidweb.cgi?T= $J S \& C S C=Y \& N E W S=N \& P A G E=$ fulltext $\& D=$ med $5 \& A N=18046409$

232. Mercken EM, Mitchell SJ, Martin-Montalvo A, et al. SRT2104 extends survival of male mice on a standard diet and preserves bone and muscle mass. Aging Cell. 2014;13(5):787-796. https://doi.org/10.1111/ acel.12220

233. Moreno-Castellanos N, Guzmán-Ruiz R, Cano DA, et al. The Effects of Bariatric Surgery-Induced Weight Loss on Adipose Tissue in
Morbidly Obese Women Depends on the Initial Metabolic Status. Obes Surg. 2016;26(8):1757-1767. https://doi.org/10.1007/s11695015-1995-x

234. Kusminski CM, Bickel PB, Scherer PE. Targeting adipose tissue in the treatment of obesity-associated diabetes. Nat Rev Drug Discov. 2016;15(9):639-660.

235. Kusminski CM, Holland WL, Sun K, et al. MitoNEET-driven alterations in adipocyte mitochondrial activity reveal a crucial adaptive process that preserves insulin sensitivity in obesity. Nat Med. 2012;18(10):1539-1549. https://doi.org/10.1038/nm.2899

236. Zimmet P, Alberti KG, Shaw J. Global and societal implications of the diabetes epidemic. Nature. 2001;414(6865):782-787. http://ovidsp. ovid.com/ovidweb.cgi?T=JS\&CSC=Y\&NEWS=N\&PAGE=fulltext\&D= med4\&AN=11742409

237. Andreux PA, Houtkooper RH, Auwerx J. Pharmacological approaches to restore mitochondrial function. Nat Rev Discov. 2013;12 (6):465-483. https://doi.org/10.1038/nrd4023

238. Giolo De Carvalho F, Sparks L. Targeting White Adipose Tissue with Exercise or Bariatric Surgery as Therapeutic Strategies in Obesity. Biology (Basel). 2019;8(1):16. https://doi.org/10.3390/biology 8010016

How to cite this article: Heinonen S, Jokinen R, Rissanen A, Pietiläinen $\mathrm{KH}$. White adipose tissue mitochondrial metabolism in health and in obesity. Obesity Reviews. 2020;21:e12958. https:// doi.org/10.1111/obr.12958 